\title{
New POU dimer configuration mediates antagonistic control of an osteopontin preimplantation enhancer by Oct-4 and Sox-2
}

\author{
Valérie Botquin, ${ }^{1}$ Heike Hess, Guy Fuhmann, ${ }^{2}$ Constantinos Anastassiadis, ${ }^{1}$ Michael K. Gross, ${ }^{3}$ \\ Gerit Vriend, ${ }^{1}$ and Hans R. Schöler ${ }^{1,4}$ \\ ${ }^{1}$ Gene Expression Programme, European M olecular Biology Laboratory (EM BL), 69117 Hei del berg, Germany
}

The POU transcription factor 0 ct-4 is expressed specifically in the germ line, pluripotent cells of the pregestrulation embryo and stem cell lines derived from the early embryo. Osteopontin (OPN) is a protein secreted by cells of the preimplantation embryo and contains a GRGDS motif that can bind to specific integrin subtypes and modulate cell adhesion/migration. We show that $0 \mathrm{ct}-4$ and $\mathrm{OPN}$ are coexpressed in the preimplantation mouse embryo and during differentiation of embryonal cell lines. Immunoprecipitation of the first intron of OPN (i-opn) from covalently fixed chromatin of embryonal stem cells by Oct-4-specific antibodies indicates that Oct-4 binds to this fragment in vivo. The i-opn fragment functions as an enhancer in cell lines that resemble cells of the preimplantation embryo. Furthermore, it contains a novel palindromic Oct factor recognition element (PORE) that is composed of an inverted pair of homeodomain-binding sites separated by exactly 5 bp (ATTTG +5 CAAAT). POU proteins can homo-and heterodimerize on the PORE in a configuration that has not been described previously. Strong transcriptional activation of the OPN element requires an intact PORE. In contrast, the canonical octamer overlapping with the downstream half of the PORE is not essential. Sox-2 is a transcription factor that contains an HMG box and is coexpressed with Oct-4 in the early mouse embryo. Sox-2 represses Oct-4 mediated activation of i-opn by way of a canonical Sox element that is located close to the PORE. Repression depends on a carboxy-terminal region of Sox-2 that is outside of the HMG box. Expression, DNA binding and transactivation data are consistent with the hypothesis that OPN expression is regulated by Oct-4 and Sox-2 in preimplantation development.

[Key Words: POU; Oct; Sox; osteopontin; preimplantation embryo]

Received March 9, 1998; revised version accepted April 14, 1998.

The fertilized oocyte undergoes cl eavage until a uni form cluster of cells, the morula, is formed. The first apparent differentiation occurs as the inner cell mass (ICM) separates from the trophectoderm during blastocoel formation (Gardner 1983). T rophectoderm refers to the epi thelial cell layer that encloses the ICM and blastocoel. Subsequently, cells dissociate from the ICM and cover its blastocoelic surface to form the hypoblast (also called primitive endoderm). These cells do not form a welldefined polarized epithelium, eventually loose cell contacts, and contain an extensive rough endoplasmatic reticulum, which is often swollen with secretory material (N adijcka and Hillman 1974). The hypoblast differenti-

Present addresses: ${ }^{2}$ Centre de Neurochimie, Laboratoire de Neurobiologie du Development et de la Régénération-Centre National de la RechercheScientifique (LNDR-CNRS) ERS10, 67084 Strasbourg, Cedex, France; ${ }^{3}$ The Salk Institute for Biological Studies, Molecular Neurobiology Laboratory, La Jolla, California 92037-1099 USA.

${ }^{4}$ Corresponding author.

E-MAIL schoeler@embl-heidebergde; FAX 6221-387 518. ates into the parietal and visceral endoderms (Gardner 1983). Parietal endoderm cells form from hypoblast precursors that migrate and adhere to the thin basal Iamina on the inner surface of the trophectoderm. In contrast, visceral endoderm cells do not migrate and consists of a columnar epithelial layer surrounding the late ICM or early epiblast (also called primitive endoderm). Relatively little is known about the molecular signals guiding cell proliferation, differentiation, and migration during establishment of these extraembryonic tissues that arise by the first differentiation events of the embryo.

Oct-4 (al so termed Oct-3 or Oct3/4) encodes a POU transcription factor (Okamoto et al. 1990; Rosner et al. 1990; Schöler et al. 1990a,b). DN A binding by POU factors is mediated by the 75-amino-acid POU-specific domain $\left(\mathrm{POU}_{\mathrm{s}}\right.$ ) and the 60-amino-acid carboxy-terminal POU homeodomain ( $\mathrm{POU}_{\mathrm{HD}}$ ) that is of the $\mathrm{C}-50$ subtype (for review, see Herr and Cleary 1995). $\mathrm{POU}_{\mathrm{S}}$ and $\mathrm{POU} \mathrm{HD}_{\mathrm{HD}}$ are connected by a linker that varies, in sequence and length, in the $>20$ metazoan POU factors that have been 
identified (Verrijzer and Van der Vliet 1993; Wegner et al . 1993; Herr and Cleary 1995). Regions outside the POU domain show no significant sequence homology.

Before gastrulation Oct-4 RN A is expressed in all cel Is of the embryo proper (Rosner et al. 1990; Schöler et al. 1990b). The proportion of embryonic cells expressing Oct-4 mRN A gradually declines as the trophectodermal and somatic lineages are established, and Oct-4 transcripts are eventually confined to the male and female germ cell lineages (Rosner et al. 1990; Schöler et al. 1990b; Yeom et al. 1996, Pesce et al. 1998a; for review, see Pesce et al. 1998b). In contrast to the immediate down-regulation of Oct-4 in trophectodermal and somatic lineages, Oct-4 protein levels are increased initially in cells of another nongerm-linetissue, namely the premigratory hypoblast (Palmieri et al. 1994). Perhaps the initial steps of visceral and parietal endoderm formation depend on increased Oct-4 expression levels. Proliferation, differentiation, and migration are three processes in which Oct-4 might be involved during formation of these tissues.

O ct-4 is also expressed in undifferentiated embryonal cell lines, each of which represent cells of distinct developmental stages (Schöler et al. 1989a,b; Okamoto et al. 1990). Cultured embryonic stem (ES) and embryonal carcinoma (EC) cells exhibit features peculiar to specific cell types found in early embryos (Robertson 1987). On the basis of biochemical markers, F9 EC cells are a model system for embryonal cells that differentiate by way of a hypoblast-like cell type into visceral or parietal endoderm cells (Strickland and Mahdavi 1978; Strickland et al. 1980; Hogan et al. 1981).

High mobility group (HM ) box proteins are transcription factors that interact functionally with POU domain proteins (Leger et al. 1995; Zwilling et al. 1995; Ambrosetti et al. 1997). Sox-2 belongs to the Sox (Sry-related HMG box-containing) gene family and is expressed in preimplantation embryos and in ES and EC cells in a similar manner as O ct-4 (Yuan et al. 1995; Collignon et al. 1996; R. Lovell-Badge, pers. comm.). Later in development, Sox-2 is again coexpressed with Oct-4 in postmigratory primordial germ cells (Collignon et al. 1996). Sox-2 and Oct-4 are able to act synergi stical ly on reporter genes in transient transfection studies (Y uan et al. 1995). The HMG box DNA-binding domain of Sry and other Sox proteins induces a strong bend on binding to the DNA (Ferrari et al. 1992; Giese et al. 1992). Thus, the role of Sry and Sry-rel ated factors may be architectural, facilitating functional protein-protein interactions on enhancers (Ferrari et al. 1992; Giese et al. 1992; Werner et al. 1995).

Understanding the molecular and genetic framework in which Oct-4 operates during the first differentiation processes in development requires identification of its target genes. Several potential target genes of Oct-4 have been proposed (Rosfjord and Rizzino 1994; Kraft et al. 1996; Liu and Roberts 1996; Saijoh et al. 1996). However, the only conclusive candidate gene in early mouse development is fgf-4 (Schoorlemmer and Kruijer 1991; Dailey et al. 1994; Rizzino and Rosfjord 1994). The fgf-4 gene has an octamer-containing enhancer downstream of the coding region, which is activated synergistically by Oct-4 and Sox-2 in transient transfection assays ( $Y$ uan et al. 1995). Furthermore, fgf-4 is coexpressed with Oct-4 and Sox-2 in the ICM (N iswander and Martin 1992) and in EC and ES cells (Schoorlemmer and Kruijer 1991).

Osteopontin (OPN; also named bone sialo protein I, 2ar, Spp1, Eta-1, and pp69) is especially abundant in bone, kidney, decidua, and various epithelial cells (for review, see Denhardt and Guo 1993; Denhardt et al. 1995). OPN is an extracellular phosphoprotein containing a GRGDS motif. This peptide motif of OPN is capable of mediating adhesion to and migration al ong the surface of cell types expressing certain classes of integrins (for review, see Eble and Kühn 1997).

In this study we show that OPN is a candidate target gene of Oct-4 during the formation of the hypoblast of mouse embryos. EC cells were used as a cell culture model for the biochemical analysis of DNA-protein interactions that occur during hypobl ast formation and differentiation. Pools of cross-linked F9 EC chromatin fragments bearing cis-acting elements that interact in vivo with Oct-4 were enriched by immunoprecipitation with Oct-4-specific antibodies. PCR analyses showed that the first intron of OPN (i-opn) was well represented in such a pool in comparison to other regions of OPN or to regulatory regions of other genes. The i-opn element contained an ES cell-specific enhancer composed of a cluster of high-affinity Oct-4-binding sites and sites for other transcription factors. In vitro, Oct-4 binds to i-opn both as a monomer and a dimer, but only the dimer confers transcriptional activation in transfection studies. Enhancer activity of i-opn is modulated in F9 EC cells through a Sox-binding site that is in close proximity to the Oct-4-binding sites. Sox- 2 in vitro binds to i-opn and in cotransfection experiments interferes with Oct-4-mediated activity. This interference depends on a region outside the HMG domain. Oct-4, Sox-2, and OPN are coexpressed in the same cells of the early mouse embryo. In addition, OPN up- and down-regulation correlates with the pattern of Oct-4 and Sox-2 expression during differentiation of F9 EC cells. We suggest that genes such as OPN are tightly regulated by Oct-4 and Sox-2 in ICM and also in hypoblast cells, which will migrate al ong the trophectoderm to become parietal endoderm.

\section{Results}

O ct-4 can be isolated as part of the embryonal chromatin

Oct-4 is a transcription factor that binds to the octamer motif ATGCAAAT with high affinity in vitro (for review, see Schöler 1991). Statistically, a haploid mouse genome contains this motif $\sim 4 \times 10^{4}$ times. Hence, an approach to isol ate target genes of Oct-4 on the basis of DN A sequence recognition al one is not feasi ble because of the high complexity of the mouse genome. One means to narrow down the pool of genes containing octamer motifs to those that may interact with Oct-4 in a physi- 
ol ogically relevant way is by isolating directly DNA sequences to which Oct- 4 is bound within the context of a nucleus. The natural arrangement of proteins bound to DN A in the nucleus is preserved by cross-linking before Iysis. Subsequent physical fragmentation yields a mixture of covalently linked aggregates of macromolecules that were in proximity of each other within the nucleus. Aggregates containing Oct- 4 can be isolated by means of Oct-4-specific antibodies and decross-linked to yield a pool of Oct-4-associated macromolecules, from which DN A fragments can be subcloned. The ideal source of such a chromatin precipitate would be from cells that normally express Oct- 4 in the animal. However, Oct- 4 is only expressed in the toti- and pluripotent cells of the early mouse embryo. These provide insufficient starting material to perform the type of biochemical isolation outlined above. Hence EC cell lines that resemble cells of the early mouse embryo were used. EC cells express Oct-4 and can be grown in large enough quantities to perform chromatin precipitation experiments.

A stringent Oct-4 immunoprecipitation procedure for covalently fixed EC cell chromatin was established based on a procedure used to investigate target genes in Drosophila (Orlando and Paro 1993). P19 EC cells were labeled with $\left.{ }^{35} \mathrm{~S}\right] \mathrm{methionine}$ and fixed with formaldehyde in vivo to preserve native protein-DN A complexes by covalent cross-linking. Covalent bonds formed between endogenous Oct-4 and nearby DN A al lows the use of stringent conditions during the subsequent purification of Oct-4-specific chromatin fragments (see Materials and Methods). Cross-linked chromatin was physically fragmented to an average DN A size of 400 bp (Fig. 1C) by an empirically cal ibrated sonication step and was fractionated on equilibrium cesium chloride ( $\mathrm{CSCl}$ ) gradients. The ${ }^{35} \mathrm{~S}$-label was used to determine protein content of each gradient fraction showing a distribution in two peaks at different $\mathrm{CsCl}$ densities (Fig. 1A, top). One peak centered at fraction 15 had a density of $\sim 1.38 \mathrm{gram} /$ $\mathrm{cm}^{3}$, whereas the second was at the top of the gradient (fraction 21). A paral lel sedimentation profile of material that had been decross-linked before centrifugation showed only one ${ }^{35} \mathrm{~S}$ peak at the top of the gradient, indicating that this material consists of uncross-linked material (Fig. 1B, top). Consequently, the $1.38 \mathrm{gram} / \mathrm{cm}^{3}$ peak was considered as the cross-linked chromatin fraction. Its density is similar to those previously reported for fixed protein-DN A complexes (Solomon et al. 1988).

Immunoprecipitation with an $\alpha$ Oct-4 antibody $(\alpha 4)$ was used to identify Oct-4 in gradient fractions of chromatin fragments decross-linked after or before fractionation. In the gradient of cross-linked chromatin fragments, Oct- 4 was detected in the fraction 15 peak but not at the top of the gradient (Fig. 1A, bottom). In contrast, Oct-4 was only detected at the top of the gradient in chromatin that was decross-linked before fractionation (Fig. 1B, bottom). Therefore, Oct-4 was crosslinked efficiently to EC cell chromatin with formaldehyde.

Both proteins and DNA that associate closely with Oct-4 in EC cell chromatin should be cross-linked to
Oct- 4 in the procedure described above. Analysis of the cross-linked proteins was investigated to define the specificity of the immunoprecipitation procedure. The set of proteins cross-linked to Oct-4 was ascertained by comparing the profiles of proteins precipitated from the fraction 15 peak by either the $\alpha 4$ antibody or total antibody from preimmune (PI) serum (Fig. 1D). The $\alpha 4 \mathrm{im}$ munoprecipitate (decross-linked just before SDS-PAGE) yielded a large number of proteins with molecular masses $>30$ kD (Fig. 1D, lane 1). The largest histone (H1) has a size of $22.5 \mathrm{kD}$, suggesting that these proteins are nonhistone. In addition, the different protein bands may represent associated proteins that bind either directly to Oct-4 or indirectly through DN A. A second precipitation of the decross-linked material with the Oct-4 antibody (Fig. 1D, double IP) gave only one band with the mobility of Oct-4, ruling out the possibility that the high apparent molecular mass of the cross-linked proteins was attributable to incomplete hydrolysis of cross-links. In contrast, PI immunoprecipitates (lane 2) contained no detectable protein, indicating that nonspecific precipitation was extremely low.

The $\alpha 4$ polyclonal antibody preparation used had been affinity purified by sequential passage over Oct-6- and Oct-4-Sepharose and was without detectable cross-reactivity in a variety of assays (Palmieri et al. 1994; data not shown). However, to ensure that the proteins immunoprecipitated by $\alpha 4$ from cross-linked chromatin were brought down by virtue of their association with Oct-4, an aliquot of the first $\alpha 4$ immunoprecipitate was decross-linked and immunoprecipitated again with $\alpha 4$. As expected, only a single band was detected that had exactly the size expected for Oct-4 (Fig. 1D, Iane 3). The $\alpha 4$ antibody precipitates the same Oct-4 band from P19 EC extracts that were not cross-linked (lane 5). Thus, the $\alpha 4$ immunoprecipitations of cross-linked chromatin can be used to isolate pools of DNA fragments that lie close to Oct-4 in chromatin in vivo.

\section{Enrichment of OPN in Oct-4 chromatin immunoprecipitates}

A second approach used to identify target genes of Oct-4 was to screen the avai lable sequence databases for genes that have octamer motifs together with other cis-acting elements that are active in early embryonal cells like Sox-2 recognition sites (Dailey et al. 1994; Yuan et al. 1995). The canonical octamer motif containing one possible A/T variation at position 5 (ATGCA/TAAT) and the Sox-binding site (TCTTTGTT) (Yuan et al. 1995) were used in one search. More than 2000 rodent sequences containing octamer motifs were found in the GenBank-EMBL sequence database. Only 17 of these contained the Sox element within $40 \mathrm{bp}$ of the octamer motif.

Oct-4 levels are increased transiently in the forming hypoblast of the developing blastocyst (Palmieri et al. 1994). Changes in cell adhesion and migration are two hallmarks of the forming hypoblast and occur during blastocyst development as the hypoblast cells delami- 
Figure 1. Immunoprecipitation of Oct-4containing chromatin of embryonal cells. (A) Protein elution profiles of isopyknic $\mathrm{CsCl}$ gradients of sheared cross-linked chromatin of P19 EC cells. (B) In parallel to equilibrium ultracentrifugation in $\mathrm{CsCl}$ the chromatin that was decross-linked before fractionation. In $\mathrm{A}$ and $\mathrm{B} \mathrm{CsCl}$ density gradients were fractionated and the ${ }^{35} \mathrm{~S} \mathrm{Iev-}$ els $(\square)$ determined in each fraction. Fraction 1 is bottom of the gradient. The Oct- 4 protein elution profile was obtained from aliquots of gradient fractions by hydrolyzing cross-links, and detected by ${ }^{35} \mathrm{~S}$ on SDS-PAGE. Lane C contains a control Oct-4 immunoprecipitate of ${ }^{35} \mathrm{~S}$-labeled P19 EC protein extracts. Exposure of the Oct-4 profile in B is three times longer than in A to show that Oct-4 was only detected at the top of the gradient. (C) Crosslinked chromatin was physically fragmented to an average DNA size of $400 \mathrm{bp}$ as determined by an agarose gel stained with ethidium bromide. (D) Immunoprecipitation of cross-linked chromatin with
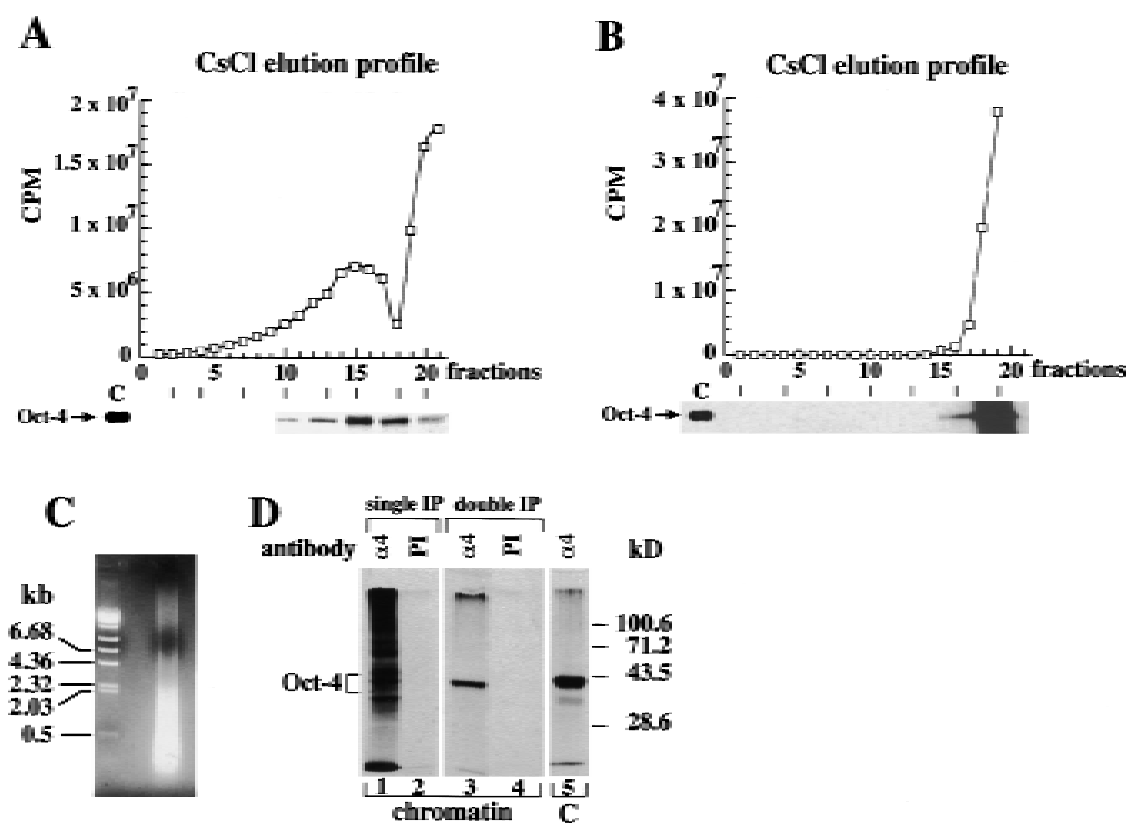

Oct-4-specific antibodies. All immunoprecipitations were performed with aliquots of fraction $15 .{ }^{35} \mathrm{~S}$-Label ed proteins in precipitates were analyzed on $10 \%$ SDS-PAGE. (Lane 1) Immunoprecipitation with Oct-4 antibodies ( $\alpha 4$ ); (Iane 2) immunoprecipitation with preimmune (PI) antibodies; (lane 3) Oct-4 immunoprecipitated chromatin was hydrolyzed and subjected to a second round of immunoprecipitation with $\alpha 4$ antibodies; (lane 4) reverse cross-linked PI immunoprecipitated chromatin was hydrolyzed and subjected to a second round of immunoprecipitation with PI antibodies; (lane 5) $\alpha 4$-immunoprecipitates of ${ }^{35}$ S-labeled P19 EC protein extract. All immunoprecipitations were done with affinity-purified Oct-4 polyclonal antibodies.

nate from the ICM, migrate, and differentiate into visceral and parietal endoderm (Gardner 1983). Of the 17 candidate elements revealed in the sequence search, OPN was the only interesting candidate target gene of Oct-4 with respect to adhesion and migration processes in the preimplantation embryo. OPN had been proposed to have a role in the adhesion and migration of various vertebrate cell types (Denhardt and Guo 1993; Denhardt et al. 1995). The closely spaced octamer and Sox elements of OPN were located in the first intron (i-opn) (Fig. 2A). An engrailed-like (TTAAAAT) sequence, which is also active in early embryonal cells (Okamoto et al. 1990; Fig. 2A), was found in close proximity to the other two elements. An enhancer in the $3^{\prime}$ nontranslated region of fgf- 4 also contains these three el ements in close proximity (Curatola and Basilico 1990). The combination of Oct- 4 and Sox- 2 results in cooperative activation of the fgf-4 enhancer in transient transfection assays (Yuan et al. 1995). Therefore, fgf-4 is a candidate target gene of Oct-4 and is likely involved in controlling cell proliferation in the early embryo (Schoorlemmer and Kruijer 1991; Dailey et al. 1994; Rizzino and Rosfjord 1994; Feldman et al. 1995).

To determine whether a physiologically relevant interaction takes place between Oct- 4 and the i-opn fragment, the rel ative abundance of this fragment in $\alpha 4$ and PI immunoprecipitates of F9 EC cell chromatin was compared (Fig. 2B). F9 cells were used instead of P19 cells because several studies had indicated that they were more similar to hypoblast cells and could be used to model hypoblast differentiation in culture (Strickland and Mahdavi 1978; Strickland et al. 1980; Hogan et al. 1981). PCR analysis revealed that the i-opn fragment containing the octamer motifs was clearly present in the $\alpha 4$ chromatin immunoprecipitates, whereas it was not
A

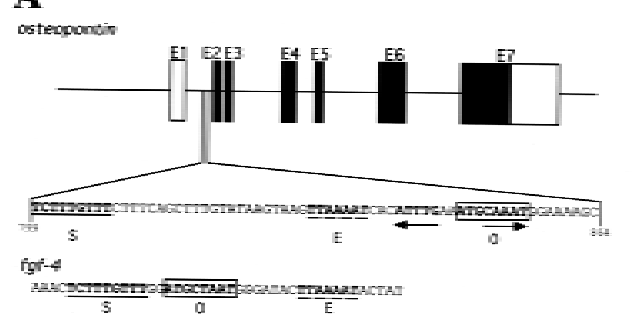

B

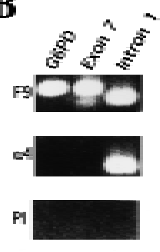

Figure 2. OPN first intron is enriched in EC chromatin $\alpha$ Oct-4 immunoprecipitates. (A) Two elements identified by a computer search for genes containing combination of potential binding sites for Oct-4 $(\mathrm{O}$, boxed) and Sox-2 ( $\mathrm{S}$, underlined). An engrailed-like factor-binding site is represented by $\mathrm{E}$, dashed line. Schematic organization of OPN gene and localization of the first intron. Solid boxes are coding regions; open boxes are untranslated regions. PORE sequence is represented by inverted arrows. (B) Enrichment of OPN first intron in $\alpha$ Oct-4 EC chromatin immunoprecipitates. PCR was performed on F9 chromatin immunoprecipitated with $\alpha$ Oct- 4 antibodies $(\alpha 4)$ or with preimmune antibodies (PI). PCR on purified F9 genomic DNA (F9) serves as a control for the PCR reactions. Primer pairs were selected to amplify a promoter region of G6PD and exon 7 and intron 1 fragments of OPN. 
detected in corresponding immunoprecipitates with PI. In contrast, the promoter and exon 7 of OPN, and a fragment containing the glucose-6-phosphate-dehydrogenase (G6PDH) promoter were not enriched in either immunoprecipitate but could be detected in F9 genomic DNA (OPN promoter not shown). Amplification of the i-opn was verified by cloning and sequencing of the 214bp band (data not shown). These data indicate that Oct-4 is closely associated with the first intron of OPN in the nuclei of undifferentiated F9 EC cells. Enrichment of the enhancer element of fgf- 4 was analyzed in the same pair of immunoprecipitates and revealed that enrichment of the fgf-4 enhancer element is 8- to 16 -fold lower than i-opn (data not shown).

Expression of OPN in embryonal cell lines and preimplantation embryos

The close association of Oct- 4 with the OPN cis-element in the nuclei of cultured cells and the presence of Oct4-binding sites in this element suggests that Oct-4 regulates physiologically the level of OPN transcription. To test this hypothesis, OPN and Oct-4 expression levels were compared by $\mathrm{N}$ orthern blot analysis of poly $(\mathrm{A})^{+}$ RNA from four different embryonal cell lines representing different stages of embryonic development (Fig. 3A; for P19 see Fig. 7A, lane 0, bel ow). M BL-1 ES cells and F9 EC cells resemble cells of the preimplantation embryo, namely ICM and early hypoblast cells, respectively (Strickland and Mahdavi 1978; Strickland et al. 1980; Hogan et al. 1981; Yeom et al. 1996). GCLB cells are derived from P19 EC cells and have many characteristics of early mesodermal cells (Pruitt 1994). All four cell lines express Oct-4 mRN A at similar levels (data not shown). Expression of OPN was strongest in F9 EC, intermediate in M BL-1 ES, weak in P19 EC, and not detected in GCLB cells (Figs. $3 A$ and $7 A$, below). These results show that OPN expression varies significantly in Oct-4-positive cell lines. The highest levels are observed in cell lines resembling the preimplantation embryo, namely in F9 EC and ES, consistent with the idea that Oct-4 up-regulates OPN expression in the ICM or hypoblast. 3T 3 cells were included in this comparison as a cell line that lacks Oct-4. The expression of OPN in the absence of Oct-4 (Fig. 3A) indicates that Oct-4 is not necessary for OPN expression in all cell types. It also suggests that the i-opn element bearing the Oct-4-binding sites may only be active during preimplantation development.

Expression of OPN was then analyzed in mouse embryos during the morula $\rightarrow$ blastocyst transition, when Oct-4 is expressed strongly and specifically in the ICM and hypoblast. Oct-4 and OPN mRN A levels were estimated by RT-PCR using primer pairs that span introns, thus eliminating the possibility of bands arising from genomic DNA or unspliced hnRNA. Similar levels of Oct-4 mRN A were detected in morulae and 3.5- or 4.5day blastocysts (Fig. 3B). In contrast, OPN mRNA was weakly detected in morulae and became clearly present in the two blastocyst stages. Thus, Oct-4 expression precedes the onset of OPN expression in preimplantation mouse embryos but is unlikely to be sufficient to activate OPN expression in morulae.

In situ hybridization experiments were performed to determine whether the expression domains of OPN and Oct-4 overlap in the developing mouse embryo. Embryos of 3.5-6.5 days postcoitum (dpc) were incubated with anti-sense DIG-labeled riboprobes of OPN (Fig. 3C). OPN was expressed weakly but selectively in the ICM of early blastocysts (Fig. 3C, $3.5 \mathrm{dpc}$ ). OPN expression was maintained in the ICM and in cells destined to form the hypoblast (Fig. 3C, $4.0 \mathrm{dpc}$ ) and was down-regulated in the hypoblast as it formed an epithelial layer of cel Is (Fig. 3C, $4.5 \mathrm{dpc}$ ). Subsequently, expression of OPN is also down-regulated in the ICM / epiblast and becomes undetectable in the embryo by 5.5 dpc (Fig. 3C). By 5.5 and 6.5 dpc OPN expression was confined to the granulated metrial gland cells (GMGC) in the placenta, which do not express Oct-4 (Fig. 3C). Expression of OPN in the

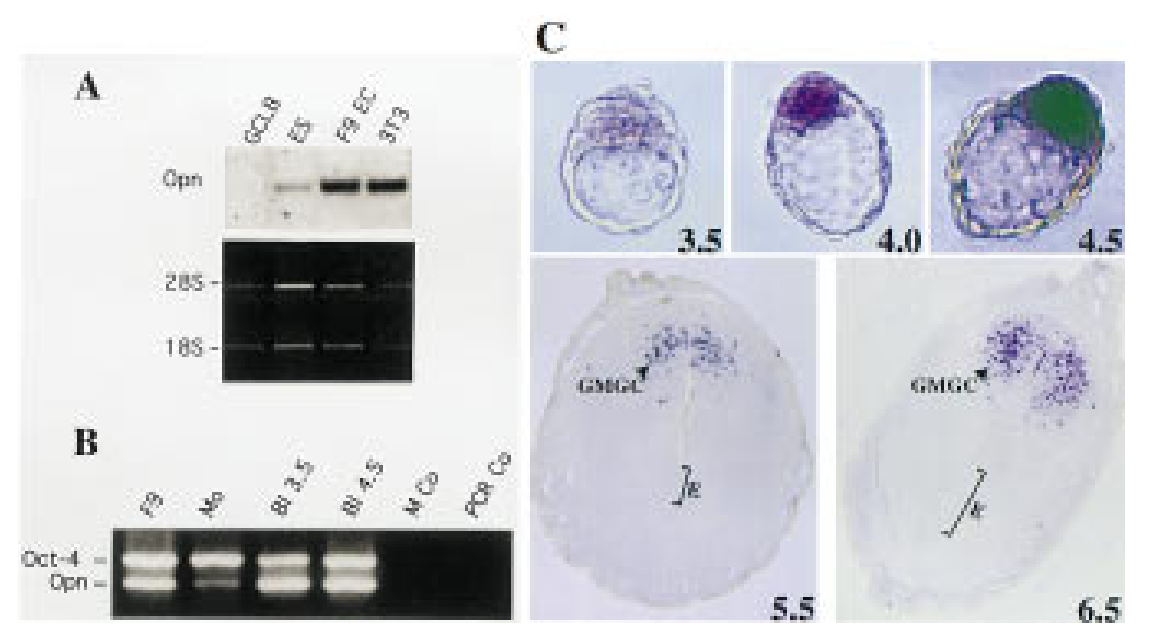

Figure 3. OPN expression in embryonal cell lines and pregastrulation embryos. (A) $\mathrm{N}$ orthern blot analyses of OPN MRNA (Opn) expression in F9 EC, GCLB, MBL-1 ES, and fibroblast (3T3) cell lines. Each lane contains $1 \mu \mathrm{g}$ of poly(A)+ RN A. mRNA levels were normalized by comparison of corresponding ethidium bromide-stained $28 \mathrm{~S}$ and $18 \mathrm{~S}$ rRNA bands. (B) RT-PCR of OPN and Oct- 4 mRN $A$ in different stages of preimplantation embryos. Multiplex PCR of Oct-4 and Opn was performed on reverse transcripts obtained from F9 cells, morulae (Mo), blastocysts of $3.5 \mathrm{dpc}$ (BI 3.5) and 4.5 $\mathrm{dpc}(\mathrm{BI}$ 4.5). PCR negative controls were done with $\mathrm{H}_{2} \mathrm{O}$ (PCR Co) and $\mathrm{M} 2$ medium treated with RN A extraction buffers and reverse transcription buffers (M Co). (C) In situ hybridization of 3.5-6.5 dpc embryos with OPN DIG-labeled mRNA. Blastocyst staining is observed in ICM and forming hypoblast, but not in trophectoderm and $4.5 \mathrm{dpc}$ hypoblast. In sections of 5.5 and $6.5 \mathrm{dpc}$ embryos only granulated metrial gland cells (GMGC) are stained. (E) embryo. Hybridization with sense probes did not generate staining (not shown). 
GMGCs is in agreement with previous results obtained with 7.5-dpc embryos (N omura et al. 1988; Waterhouse et al. 1992). OPN and Oct-4 expression only overlap in preimplantation embryos, suggesting that this is the physiological time and space at which OPN may be a target of Oct-4 control.

Coexpression of OPN and Oct-4 in embryonic cell lines and overlapping expression domains in preimplantation embryos, taken in combination with the enrichment of an Oct-4-binding intron of OPN in $\alpha 4$ chromatin immunoprecipitates, clearly suggests a physiological link between the transcription factor Oct-4 and the cell adhesion molecule OPN. However, Oct-4 and OPN transcript levels do not correlate strictly temporally and quantitatively, suggesting that factors in addition to Oct-4 are involved in the regulation of OPN expression during development and in embryonal cell lines.

O ct-4 binds to a 36-bp EC cell-specific enhancer within i-opn

Enrichment of i-opn in $\alpha 4$ chromatin immunoprecipitates strongly suggests that this piece of DNA provides the interface at which the Oct-4 transcription factor controls OPN mRNA levels. The occurrence of a perfect octamer motif (in an inverted dyad configuration with an imperfect octamer motif), a Sox motif, and an engrailedlike motif in a short sequence ( +799 to $+864 \mathrm{bp})$ of the i-opn fragment ( +758 to $+1077 \mathrm{bp})$ further suggests that these sites and the proteins that interact with them provide the combinatorial regulatory complex that governs the expression of OPN in preimplantation development. Electrophoretic mobility-shift assays (EMSAs) were performed as an initial means to establish which DNAprotein interactions can occur. Bacterially expressed Oct-4 was incubated with an end-labeled fragment of intron 1 ( +758 to +1077 bp). Part of the radi oactive probe was shifted to a position of lower mobility. Incubation of the mixture with Oct-4-specific antibodies abolished the
Iow mobility band, demonstrating that Oct-4 can bind to i-opn (data not shown; see below).

The i-opn fragment was inserted in front of a minimal herpes simplex virus thymidine kinase (HSV tk) promoter driving the expression of the luciferase reporter gene to test whether it was active in cells expressing O ct-4 (Fig. 4A, i-opn). Point mutations were introduced into the octamer sequence to measure the contribution of the octamer site to the i-opn activity (Fig. 4A, i-opn mut). A short i-opn region (OS), containing only the Sox, engrailed-like, and octamer-binding sites, was also analyzed for activity (Fig. 4A). The i-opn-contai ning reporter was 4.8 times more active in transiently transfected F9 EC cells than the parental vector without insert (Fig. 4C). Similar activity was obtained with the OS reporter (Fig. 4C). In contrast, the reporter bearing a mutated i-opn (i-opn mut) lacked detectable activity (Fig. 4C). Therefore, i-opn contains cis-acting elements, in particular the octamer site, that confer expression in F9 EC cells.

To assess the activity of the octamer motif in i-opn, short fragments containing the octamer dyad and engrailed-like motif (Fig. 5B, O oligonucleotide; positions +827 to +863 ) were oligomerized and tested in transactivation assays. Six and 10 direct repeats of the $O$ oligonucleotide were inserted into the tk luciferase reporter plasmid (Fig. 4A ). Expression of these reporters was compared to the parental reporter by transient transfection assays. Reporters bearing $\mathrm{O}$ repeats showed significantly higher levels of luciferase activity than parental reporters in F9 EC but not in 3T3 cells (Fig. 4D). These results demonstrate that a 36-bp-long region within i-opn can confer EC cell-type specificity when multimerized and suggests that this element provides the interface at which Oct-4 acts to regulate OPN during preimplantation development.

\section{O ct- 4 binds as a monomer and dimer to the $\mathrm{O}$ element}

The interaction of Oct-4 and other POU domain tran-
Figure 4. OPN first intron functions as an ECspecific enhancer. (A) Reporter constructs. HSV tk minimal promoter cloned upstream of the Iuciferase gene (LuC); i-opn and i-opn mut are PCR fragments of the OPN first intron from +758 to +1077 wild-type and point mutated octamer motif, respectively; OS denotes OPN first intron from +796 to $+863.6 \times 0$ and $10 \times 0$ denote 6 or 10 copies of the $O$ oligonucleotide, respectively. All fragments were cloned upstream of $-37 t k l u c$. (B) Oligonucleotide $O$ represents a short fragment of $\mathrm{i}$-opn that binds to Oct-4. The octamer motif is boxed and the PORE is represented by two inverted arrows. (C,D) F9 (solid bars) and 3T 3 (open bars) cells were transfected transiently with $10 \mu \mathrm{g}$ of respective reporter and $2 \mu \mathrm{g}$ of human $\beta$-actinLacZ used as an internal standard to normalize luciferase activity. Fold activation refers to the quotient of luciferase activities in the test and control (tkluc) construct.
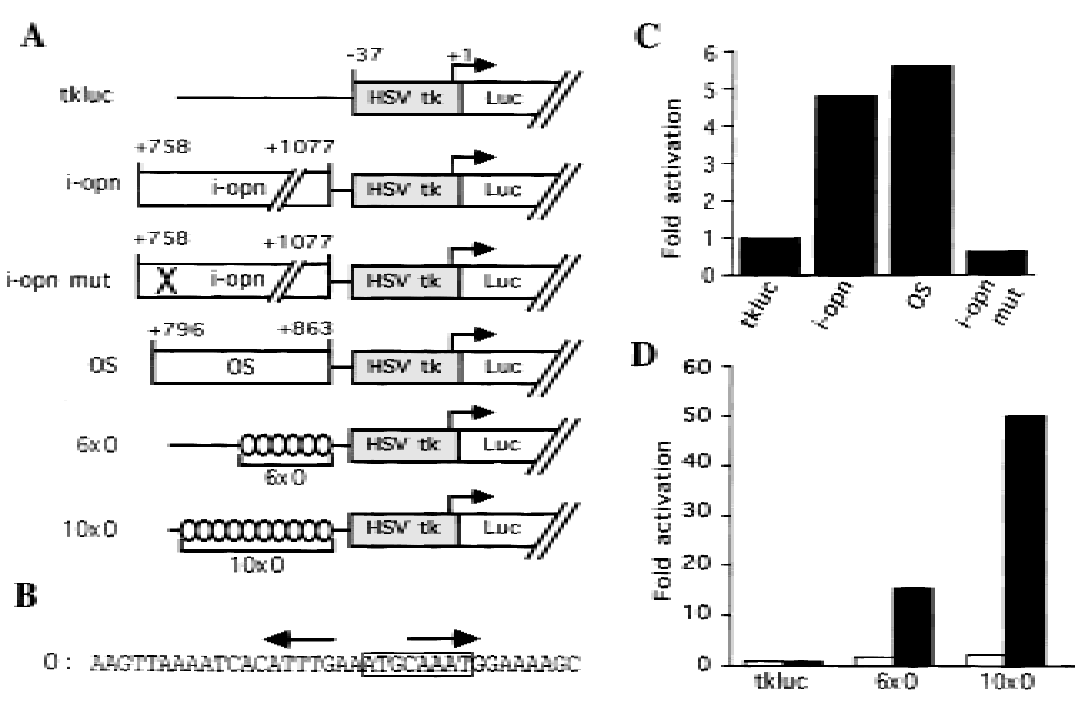


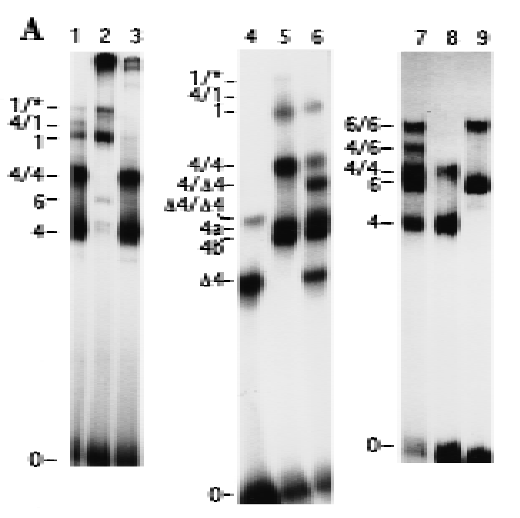

B
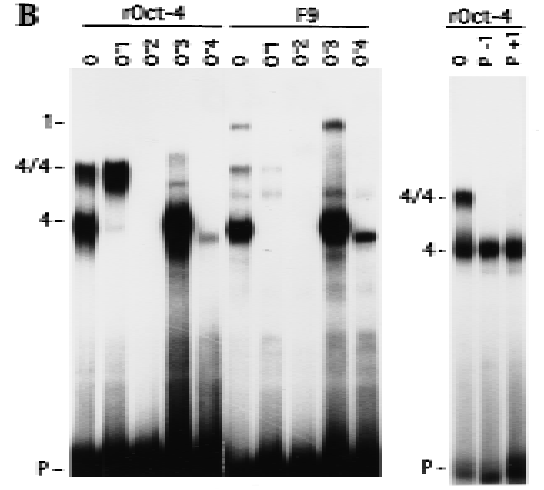

C

Dimer-Manomer binding sibe mutations $\sigma^{-1}\left(\mathrm{D}^{+} \mathrm{M}^{-} \mathrm{J}\right.$ $0 \mathrm{cos}^{-1}$

$022(\mathrm{~L}-\mathrm{M}-1$

$014, \mathrm{D}^{-} \mathrm{M}^{-} \mid$

Phasing nutratian

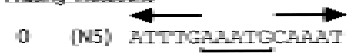

PP -1 (N4) MTITIAPHTGCARAT

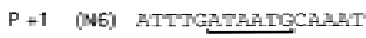

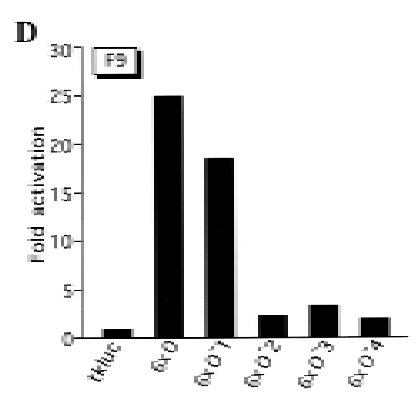

Figure 5. Oct-4 binding to and transactivation by the PORE (A) EMSA demonstrating Oct-4 homo- and heterodimerization on a PORE-containing oligonucleotide (O). (Lane 1) F9 cell extracts; (lane 2) F9 cell extracts incubated with Oct-4 antibodies; (lane 3) F9 cell extracts incubated with Oct-1 antibodies; (lane 4) COS extract containing an Oct-4 protein lacking 98 amino acids at the amino terminus; (lane 5) F9 EC cell extract; (lane 6) mixture of extracts used in lanes 4 and 5; (lane 7) mixture of purified recombinant Oct-4 and Oct-6; (lane 8) recombinant Oct-4; (lane 9) recombinant Oct-6. (B) EM SA of recombinant Oct-4 (rOct-4) and F9 extracts (F9) with the $\mathrm{O}$ oligonucleotide and mutated versions thereof (see O) $\mathrm{O}^{-1}, \mathrm{O}^{-2}, \mathrm{O}^{-3}, \mathrm{O}^{-4}$, $\mathrm{P}^{-1}$, and $\mathrm{P}^{+1}$ in $\left.\mathrm{C}\right)$. (P) Free probe. Complexes in $A$ and $B$ are as follows: (1) Oct-1 monomer; (4) Oct-4 monomer; the complexes labeled $4 \mathrm{a}$ and $4 \mathrm{~b}$ correspond to Oct-4 monomer in mobility and are considered to represent two differentially phosphorylated forms of Oct-4 (V. Botquin, unpubl.). These bands are not clearly resolved in lanes 1 and 3 of $A$, lane $O$ with F9 extracts of $B$ and therefore, are merely label ed 4. $(1 / *)$ Oct-1 homo- or heterodimer; (4/4) Oct-4 homodimer; $(\Delta 4 / \Delta 4)$ homodimer of truncated Oct-4; $(4 / \Delta 4)$ heterodimer of full-length and truncated Oct-4; $(6 / 6)$ Oct-6 homodimer; $(4 / 1)$ heterodimer of Oct-4 and Oct-1; $(4 / 6)$ heterodimer of Oct-4 and Oct-6. (C) Specific point and phasing mutations in O oligonucleotide to analyze binding and transactivation requirements in $B$ and $D$. Point mutations were introduced at base pairs predicted to make central contacts with the POU $U_{S}$ domain $\left(\mathrm{O}^{-1}\right)$, the $\mathrm{POU}_{\mathrm{HD}}\left(\mathrm{O}^{-3}, \mathrm{O}^{-4}\right)$, or both $\left(\mathrm{O}^{-2}\right)$. Oligonucleotides capable of binding Oct-4 as a dimer or a monomer are denoted by $\mathrm{D}^{+}$and $\mathrm{M}^{+}$, respectively. (N) N umber of nucleotides between the two half sites of the PORE. The octamer motif is boxed and the PORE is labeled by two inverted arrows. Dots represent nucleotides identical to those in oligonucleotide O. (D) Transactivation by mutated versions of oligonucleotide $\mathrm{O} .6 \times \mathrm{O}, 6 \times \mathrm{O}^{-1}, 6 \times \mathrm{O}^{-2}, 6 \times \mathrm{O}^{-3}$, and $6 \times \mathrm{O}^{-4}$ are six copies of $\mathrm{O}, \mathrm{O}^{-1}, \mathrm{O}^{-2}, \mathrm{O}^{-3}$, and $\mathrm{O}^{-4}$, respectively, inserted upstream of tkluc. All constructs contain a TATA box at similar distances from the insert. F9 EC cells were transfected transiently with $10 \mu \mathrm{g}$ of respective reporter and $2 \mu \mathrm{g}$ of human $\beta$-actin LacZ, which served as an internal standard to normalize luciferase activities for transfection efficiency. Fold activation refers to the quotient of luciferase activities in test and control (tkluc) constructs.

scription factors with the octamer motif, and various synthetic derivatives thereof, has been studied extensively (for review, see Schöler 1991; Verrijzer and van der Vliet 1993; Herr and Cleary 1995; Ryan and Rosenfeld 1997). However, few studies have examined this interaction using octamer motifs embedded in naturally occurring sequence contexts, using physiologically relevant cell extracts. Therefore, the O oligonucleotide was tested in an EMSA for binding with proteins from F9 EC cell extracts (Fig. 5A). Three of the five complexes observed contained Oct- 4 because they were removed by addition of Oct-4-specific antibodies (Fig. 5A, cf. Ianes 1 and 2). The complex labeled 4/4 corresponds to a dimer of Oct-4 bound to the $\mathrm{O}$ oligonucleotide (see bel ow). A third band, labeled 4/1, was composed of Oct-4 and Oct-1 because it was abolished by both Oct-1 and Oct-4 antibodies (lanes 2,3). In addition, two other Oct-1 complexes, labeled 1 and $1 / *$, were recognized by Oct- 1 antibodies (lane 3).

Oct-4-containing compl exes were further investigated by using purified recombinant Oct-4 (rOct-4). Bacterially expressed Oct-4 generated two complexes when incubated with the $\mathrm{O}$ oligonucleotide (complexes 4 and 4/4; Fig. 5B, lane $\mathrm{O}$, left and right). Both have similar mobili- ties as Oct-4 complexes obtained with F9 EC cell extracts, suggesting that in EC cells these complexes contained only Oct-4 (Fig. 5B, cf. lanes O in rOct-4 and F9).

To determine the number of Oct-4 molecules within these complexes, two extracts containing Oct-4 proteins of different size were mixed before EM SA (Fig. 5A, Iane 6). The shorter version of Oct-4 was expressed in COS cells (Fig. 5A, lane 4, complex labeled $\Delta 4$ ) and lacks 98 amino acids at the amino terminus (160ct-4; Schöler et al. 1990b). The longer version of Oct-4 was the complete protein from F9 EC cells (Fig. 5A, lane 5, complex labeled $4 a / 4 b)$. The truncated Oct-4 protein formed two bands ( $\Delta 4$ and $\Delta 4 / \Delta 4)$, each with higher mobility than corresponding bands with the complete protein $(4 a, 4 b$ and $4 /$ 4; Fig. 5A, cf. Ianes 4 and 5). N ontransfected COS cells did not give rise to these complexes, indicating that these complexes contained Oct-4 protein (data not shown). Mixed extracts (Fig. 5A, lane 6) containing both Oct-4 versions gave a set bands that was a composite of the two individual extracts. However, in addition, a complex of intermediate mobility was observed between $4 / 4$ and $\Delta 4 / \Delta 4$, which was composed most likely of one short and one long version of Oct-4 (4/ $\Delta 4)$. Thus, 
Oct-4 can bind to the $\mathrm{O}$ fragment of $\mathrm{i}$-opn as a monomer, a homodimer, or, together with Oct-1, as a heterodimer.

To further investigate the ability of Oct-4 to heterodimerize with other POU factors, EMSA was performed using a mixture of purified Oct-4 and rOct-6 (Fig. $5 A$, Ianes 7-9). Similarly to Oct-4, Oct-6 formed monomer and homodimer complexes on the $\mathrm{O}$ oligonucl eotide (complexes 6 and 6/6; Ianes 8,9). In addition to the set of complexes obtained by individual Oct-4 and Oct- 6 proteins, an additional band $4 / 6$ of intermediate mobility between $4 / 4$ and $6 / 6$ was observed after mixing both proteins together (Fig. 5A, lane 7). This shows that Oct-4 can heterodimerize with both Oct- 6 and Oct- 1 .

O ct-4 dimer formation requires the palindromic sequence ATTTG $\mathrm{N}_{5}$ CAAAT.

The $O$ fragment contains the canonical octamer motif ATGCAAAT that is bound by several POU proteins. $\mathrm{POU}_{\mathrm{S}}$ binds to the first and POU ${ }_{H D}$ to the second half of this motif (Klemm et al. 1994). An inverted CAAAT sequence is located 5 nucleotides upstream of the CAAAT in the octamer motif (Fig. 5C). This dyad sequence motif was likely to be required for the formation of Oct-4 dimer complexes. Point mutations were introduced at various positions within the $\mathrm{O}$ oligonucleotide to determine which residues were required for Oct-4 monomer and dimer formation. The mutagenesis strategy was designed to reduce specifically binding of either $\mathrm{POU}_{\mathrm{S}}\left(\mathrm{O}^{-1}\right)$ or $\mathrm{POU} H \mathrm{HD}\left(\mathrm{O}^{-3}, \mathrm{O}^{-4}\right)$ of Oct-4, or both $\left(\mathrm{O}^{-2}\right)$ (Fig. $5 \mathrm{C}$, dimer-monomer-binding site mutations). This was performed by altering critical residues of the dyad motif that are predicted, based on the known crystal structure of a POU domain-DNA complex, to make contacts with these two subdomains (Klemm et al. 1994). Mutated oligonucleotides were incubated with either bacterially expressed Oct-4 (rOct-4) or F9 EC cell extracts and analyzed by EMSA (Fig. 5B, left).

rOct-4 binds as a monomer and a dimer to the wildtype oligonucleotide (Fig. 5B, lane O). When a mutation in the first half of the octamer motif was introduced, only rOct-4 monomer formation was affected (lane $\mathrm{O}^{-1}$ ). In contrast, dimerization of rOct-4 was abol ished specifically by a mutation in the ATTTG (inverted CAAAT) sequence located $5^{\prime}$ to the octamer motif (lane $\mathrm{O}^{-3}$ ). When both mutations were combined neither dimer nor monomer were detected (lane $\mathrm{O}^{-2}$ ).

A point mutation was introduced into the second half of the octamer motif to test whether the right half site of the palindromic sequence is also required for dimer formation (lane $\mathrm{O}^{-4}$ ). Indeed, dimer formation on this oligonucleotide was abolished and binding of the monomer was reduced drastically. The mobility of the monomer complex was also slightly increased in comparison to that formed on the wild-type sequence, possibly as a result of a different binding mode. One likely explanation is that the homeodomain now can only bind to the left half site of the palindrome (inverted CAAAT). An altered binding conformation could result in different DNA bending and, as a consequence, in altered mobility of the complex (Verrijzer et al. 1991).

Oligonucleotides with one nucleotide inserted or deleted between the palindromic motifs were also tested with rOct-4 for dimer formation (Fig. 5C, phasing mutations). In neither case was the dimer complex formed, indicating dimerization is highly dependent on proper spacing of the two Oct-4 molecules bound to the palindrome (Fig. 5B, right). The phasing mutations also abolished the formation of Oct-4 homo- and Oct-4/Oct-1 heterodimers in F9 EC cell extracts (data not shown). The specific amino acid side chains required for dimer formation have to be determined.

Oct-4 of F9 EC cell extracts and rOct-4 basically gave the same pattern of compl exes with all oligonucleotides (Fig. 5B, cf. left and right). However, dimer formation with rOct-4 was far more efficient than with F9 Oct-4 (cf. both $\mathrm{O}$ lanes). In addition, the mutation $\left(\mathrm{O}^{-1}\right)$ that abolished monomer formation and increased dimer formation with rOct-4 (two- to threefold; compare $\mathrm{O}_{\text {and }} \mathrm{O}^{-1}$ lanes), reduced monomer but did not increase dimer formation in F9 EC extracts. These results suggest that Oct-4 in F9 EC extracts is modified in a way that interferes with dimerization.

The mutagenesis assays presented above indicate that formation of the monomer complex requires an intact $\mathrm{POU}_{\mathrm{S}}$ half site and at least one intact POU $\mathrm{HD}_{\mathrm{D}}$ half site. The POU ${ }_{H D}$ half site of the octamer motif results in a more stable monomer complex than the inverted halfsite found upstream. In contrast, formation of the Oct-4 dimer complex on the $\mathrm{O}$ fragment requires two intact POU $_{H D}$ half sites but does not require an intact POU half site. Dimerization of Oct-4 depends on the palindromic motif ATTTG-CAAAT, which has to be spaced by five nucleotides. This motif will be subsequently called PORE, for palindromic Oct recognition element.

\section{PORE mediates function of the EC cell enhancer}

To determine whether monomer or dimer complexes were mediating the EC cell-specific enhancer function of i-opn, mutagenized oligonucl eotides were multimerized and inserted at position -37 in the standard tk luciferase reporter plasmid. The reporter activity of each mutant O-multimer was compared to the activity generated by the wild-type O-multimer $(6 \times 0)$ in transient transfections in F9 EC cells (Fig. 5D). Hexamers of the $\mathrm{O}^{-1}$ fragment, which only binds Oct-4 as a dimer (Fig. 5B, left), activated the reporter in a manner similar to the hexamer of the wild-type sequence (Fig. 5D, cf. $6 \times 0$ with $\left.6 \times \mathrm{O}^{-1}\right)$. In contrast, a hexamer of the $\mathrm{O}^{-3}$ fragment, to which Oct-4 bound only as a monomer, activated transcription only two- to threefold $\left(6 \times \mathrm{O}^{-3}\right)$. This was only slightly above the level of activation by hexamers of $\mathrm{O}^{-2}$, to which Oct-4 could not bind at all $\left(6 \times \mathrm{O}^{-2}\right)$. These results demonstrate that the PORE and not the octamer motif activates transcription of the reporter gene efficiently. They suggest that the PORE is also important for the function of the EC-cell-specific enhancer found in i-opn. The in vitro binding data sug- 
gest that PORE activity in vivo depends on Oct-4 homoor heterodimerization with either Oct-1 or Oct-6.

\section{Sox-2 interferes with Oct-4-mediated transcriptional} activation

The variation in OPN expression levels in different ES and EC cell lines (see Fig. 3A) may be attributable to differences in Oct-4 dimerization or binding of other regulatory factors. However, Oct-4 mRNA and protein levels do not vary in the ES and EC cell I ines examined so far. In addition, monomer binding is similar in all extracts of these cell types (Yeom et al. 1996; data not shown). As an initial test to determine whether OPN expression is modulated by different dimer levels, in vitro dimer formation was compared in different embryonic cellular extracts (Fig. 6A, left). Oct-4 dimer formation was very similar in all cell extracts and thus cannot explain why OPN levels vary in the ES and EC cells. However, we observed an inverse correlation between OPN expression and the presence of the 4/1 and 1 /* complexes, suggesting that an Oct-4/Oct-1 dimer could repress the activity of the i-opn enhancer.

Sox-2 is another candidate transcription factor that could modulate Oct-4-mediated activity of i-opn. The Sox-binding site was used in our initial computer analysis to restrict the number of potential Oct-4 target genes (see Fig. 2A). Oct-4 and Sox-2 proteins increase transcription synergistically from the fgf-4 enhancer activity (Yuan et al. 1995). An oligonucleotide spanning the i-opn region with the canonical Sox-binding site (S oligonucleotide) was used to test for differences in Sox-2-binding activity in ES and EC cell lines (Fig. 6A, right). One major complex was formed in F9, P19, and ES cells. A common test for Sox-factor binding is the competition by poly[d(I-C)] (Dailey et al. 1994). Incubation of the reaction mixture with poly[d(I-C)] instead of poly[d(G-C)] resulted in a specific competition of the Sox-2 complex [Fig. 6A, lanes ES(IC) and F9 EC(IC)]. In addition, point mutations within the Sox motif decreased formation of this complex (data not shown; see below). Finally, in both F9 EC and ES extracts, Sox-2 binding was affected specifically by Sox-2 anti bodies [Fig. 6A, lanes ES $(\alpha 2)$ and F9 EC $(\alpha 2)$ ]. The Sox-2 complex varies in extracts of the different cell types. The strongest signal was obtained with ES cell extracts, a weaker band with F9 EC and P19 EC (Fig. 6A, right). Finally, no Sox-2 complex could be detected in GCLB and 3T3 (Fig. 6A, right).

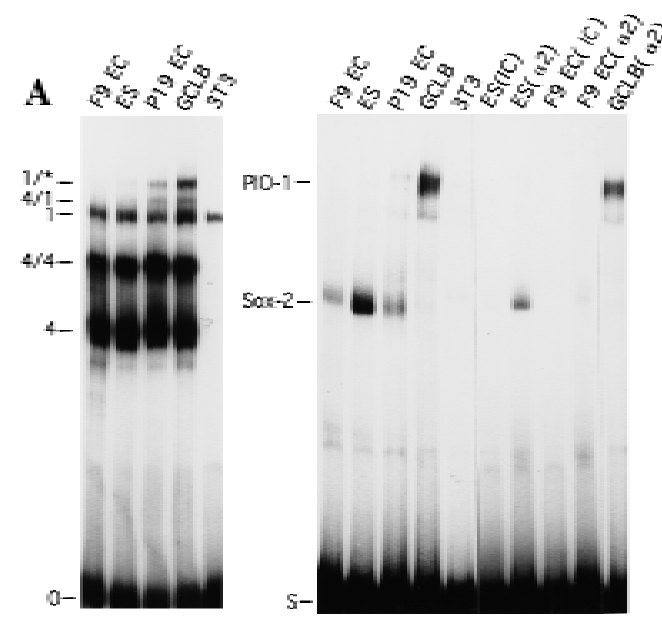

D
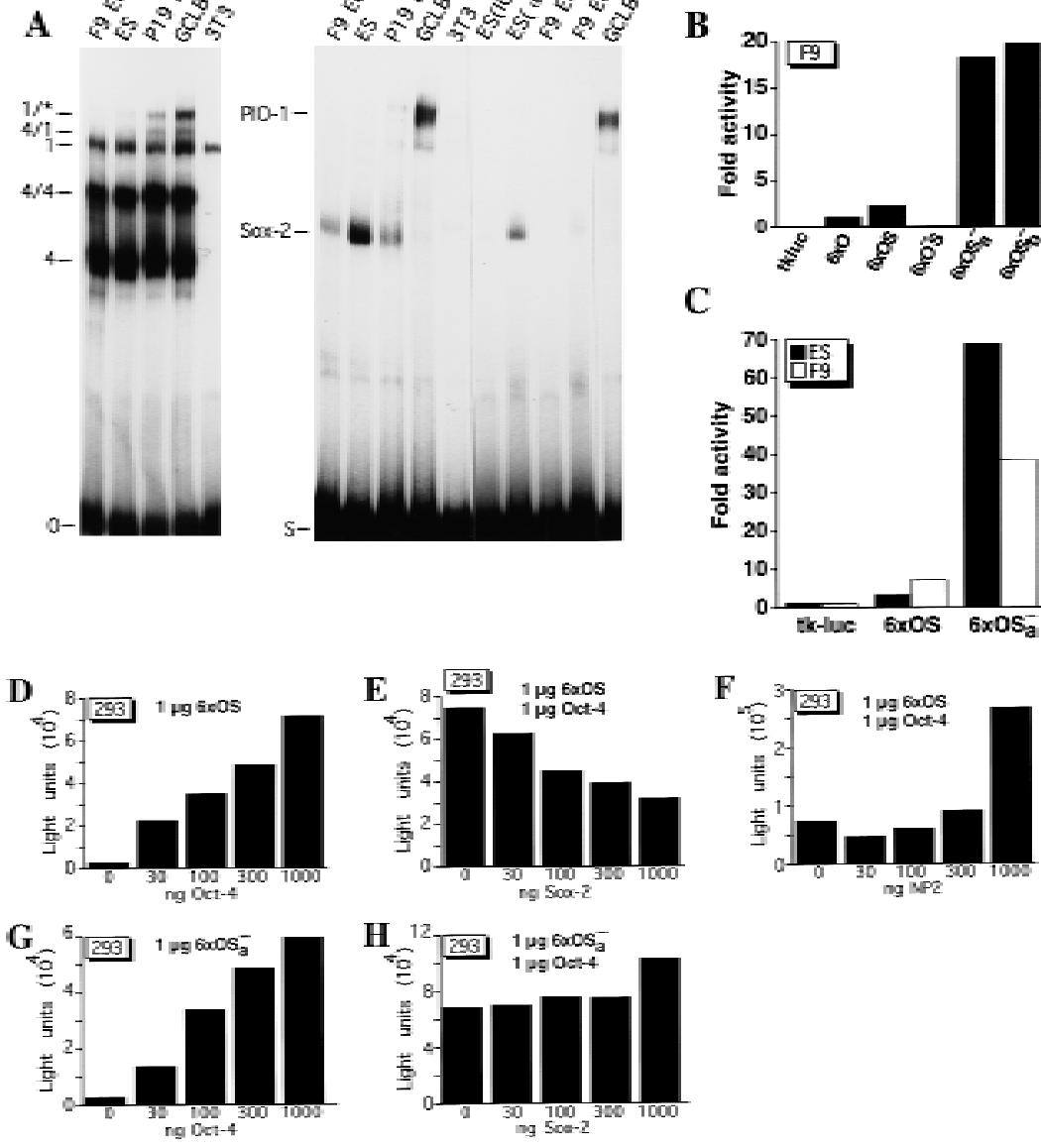

C

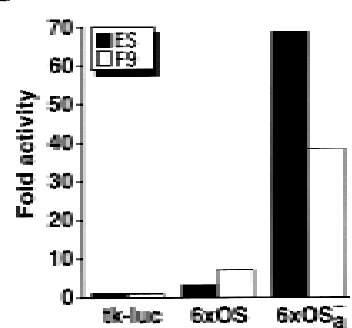

por constant amount of CMVOct-4 and increasing amounts of CMVSox-2 effector. (F) Cotransfection assay in 293 cells of $1 \mu \mathrm{g}$ of $6 \times$ OS reporter, constant amount of CM VOct- 4 and increasing amount of CM VN P2 effector. (G) Cotransfection assay in 293 cells of $1 \mu \mathrm{g}$ of $6 \times \mathrm{OS}_{\mathrm{a}}^{-}$reporter and increasing amount of CMVOct-4 effector. (H) Cotransfection assay in 293 cells of $1 \mu \mathrm{g}$ of $6 \times \mathrm{OS}_{\mathrm{a}}^{-}$reporter, constant amount of CMVOct-4 and increasing amounts of CMVSox-2 effector. All luciferase activities were normalized for $\beta$-galactosi dase expression. Light units refers to the units of luciferase counts. 


\section{Botquin et al.}

A novel low mobility complex [PIO-1 (proteins binding to intron 1 of osteopontin)] formed on the S oligonucleotide when P19 EC and GCLB cell extracts were used (Fig. 6A). The identities of proteins in PIO-1 are unclear. PIO-1 is unlikely to contain Sox-2 because it was not affected by Sox-2 antibodies [Fig. 6A, right, GCLB $(\alpha 2)$ ]. Sox-2 and PIO-1 binding is found predominantly in ES and EC cells in which OPN expression is low or undetectable, namely in ES, P19 EC, and GCLB. Thus, the presence of the Sox-2 and PIO-1 can be correlated with the expression pattern of OPN in cell lines corresponding to different embryonic cell types.

The activity of the Sox-2-binding site was analyzed in transient transfection assays. The hexamer of the S oligonucleotide in front of the tk luciferase reporter was inactive in F9 EC cells, confirming previous results that a Sox-2-binding site by itself cannot activate transcription (data not shown, Yuan et al. 1996). To study the functional interaction of Sox-2 and Oct-4, longer oligonucleotides spanning both the Oct and the Sox motifs (termed OS) were oligomerized and cloned in front of the standard reporter (position +798 to +863). Tandem hexamers of the native sequence $(6 \times 0 S)$ were inserted upstream of the tk luciferase reporter and compared to tandem hexamers of mutated versions. Mutations were either in the octamer motif $\left(6 \times \mathrm{O}^{-} \mathrm{S}\right)$ or in the Sox-binding site $\left(6 \times \mathrm{OS}_{\mathrm{a}}{ }^{-}\right.$; complete replacement; $6 \times \mathrm{OS}_{\mathrm{b}}{ }^{-}$; point mutated site). In vitro binding analyses indicated that Sox-2 binding to $\mathrm{Os}_{\mathrm{a}}{ }^{-}$and $\mathrm{Os}_{\mathrm{b}}{ }^{-}$was undetectable or weak, respectively (not shown). Reporter constructs were transfected into F9 EC cells and their activity was analyzed (Fig. 6B). The wild-type hexamer $6 \times$ OS was twice as active as the shorter $6 \times 0$ fragment. The activity of $6 \times$ OS depended on intact Oct factor-binding sites, because the mutated counterpart $\left(6 \times \mathrm{O}^{-\mathrm{S}}\right)$ was inactive. Strikingly, mutations of the Sox-binding site $\left(6 \times \mathrm{OS}_{\mathrm{a}}{ }^{-}\right.$ and $6 \times \mathrm{OS}_{\mathrm{b}}$ ) resulted in an additional 9.5- to 10-fold activation (Fig. 6B, cf. $6 \times \mathrm{OS}_{\text {with }} 6 \times \mathrm{OS}_{\mathrm{a}}{ }^{-}$and $6 \times \mathrm{OS}_{\mathrm{b}}{ }^{-}$). These results indi cate that the Sox-binding site is a negative element that interferes with the activity of other elements within the OS fragment, most likely with the activity of the Oct-4-binding sites.

Sox-2-binding intensity differs in ES and in F9 EC cell extracts (Fig. 6A, right). We compared the activity of the wild-type hexamer $6 \times$ OS in these two cell types (Fig. $6 C)$. The $6 \times$ OS reporter was twice more active in F9 EC compared to ES cells and thus the OS activity correlated inversely with Sox-2-binding intensity. In addition, mutation of the Sox-binding site $\left(6 \times \mathrm{OS}_{\mathrm{a}}\right)$ resulted in an additional 20-fold activation in ES compared to a fivefold activation in F9 EC cells (Fig. 6C). This suggests that Sox-2 may decrease the level of OPN expression in ES cells. PIO-1 may act as another negative factor involved in a down-regulation of OPN in GCLB and P19 EC cells (Fig. 6A, right).

To assess directly the effect of Sox-2 on Oct-4, both factors were cloned into CMV vectors and expressed in 293 cells. First, increasing amounts of the Oct-4 expression vector was cotransfected with a constant amount of the $6 \times$ OS reporter (Fig. 6D). Reporter activity was in- creased in direct proportion with the amount of the expression vector added. The highest amount $(1 \mu \mathrm{g})$ tested in this experiment stimulated the reporter $>20$-fold. Subsequently, increasing amounts of the Sox-2 expression vector was cotransfected with a constant amount of both the Oct-4 expression and the $6 \times$ OS reporter vectors. In this case, increased amounts of Sox-2 expression vector steadily decreased the activity mediated by Oct-4 (Fig. $6 E)$. This negative effect depended on an intact Sox element because even the highest amount of Sox-2 did not interfere with Oct-4-stimulated activity of $6 \times \mathrm{OS}_{\mathrm{a}}{ }^{-}$reporter (Fig. 6G,H). These results indicate that Sox-2 can reduce levels of Oct-4-mediated transactivation from the $6 \times$ OS reporter and that binding of Sox- 2 protein to the canonical Sox motif is required for its repressive effect.

A transactivation domain has been mapped to the carboxy-terminal portion of Sox-2 (Yuan et al. 1995). To determineits contribution to the repressive effect of Sox2 , a truncated version lacking this region was cotransfected with a constant amount of both $6 \times$ OS reporter and Oct-4 expressi on vectors. Increasing amounts of the truncated Sox-2 protein (N P2) sti mulated the reporter up to threefold (Fig. 6F). This activation by NP2 is in striking contrast to the decrease mediated by the complete protein and might indicate an architectural modification of the chromatin-facilitating Oct-4 interaction with the basal transcriptional machinery. The result suggests that transcriptional repression by Sox-2 is not likely attributable to competitive binding of Sox- 2 with another transcription factor, rather it is the result of the carboxyterminal region of Sox-2 that interferes with Oct-4-mediated transcriptional activation.

\section{Oct-4, Sox-2, and OPN expression correlate during hypoblast differentiation}

The ICM of the blastocyst, which coexpresses Oct-4, Sox-2, and OPN, differentiates into the epiblast and hypoblast (Gardner 1983; Palmieri et al. 1994; R. LovellBadge, pers. comm.; see Fig. 3C). The hypobl ast is I ocalized initially to the blastocoelic surface of the ICM and gradual ly spreads over the inner surface of the blastocoel as it differentiates into parietal and visceral endoderm (Gardner 1983). Oct-4 protein level s increase in cel Is that form the hypobl ast, but decrease drastically as the hypoblast differentiates further (Palmieri et al. 1994). In contrast, Sox-2 expression is down-regulated immediately in cells of the hypoblast lineage ( $R$. Lovell-Badge, pers. comm.).

F9 EC cells are often used as a cellular model to study hypoblast-specific questions (Strickland and $M$ ahdavi 1978; Strickland et al. 1980; Hogan et al. 1981). In a first attempt to compare Oct-4 and OPN expression levels during this specific stage, F9 EC cells were induced to differentiate into parietal and visceral endoderm (Fig. 7A, nonaggregates and aggregates, respectively). In both differentiation modes F9 EC cells are considered to initially pass through a hypobl ast-like stage (Adamson 1986). Undifferentiated F9 EC cells expressed moderate levels of Oct-4 and OPN (Fig. 7A, F9 lane 0 in each panel). A 


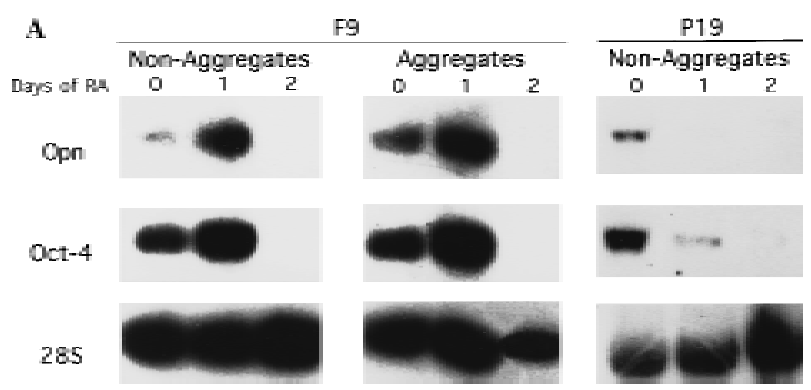

B
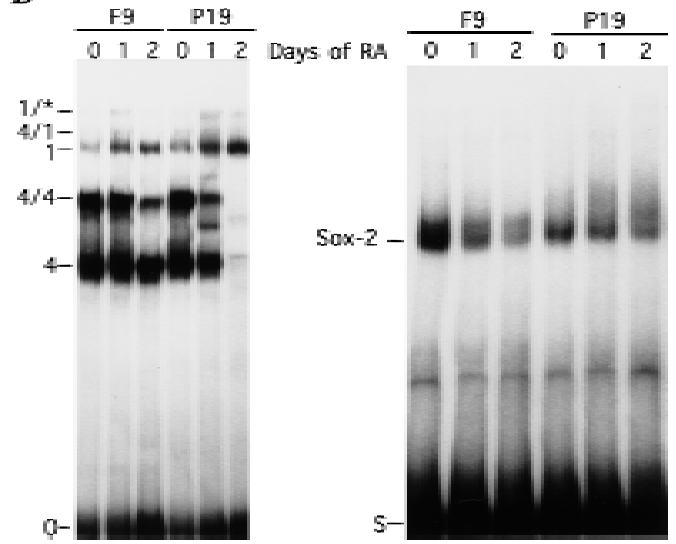

Figure 7. Correlation of OPN, Oct-4, and Sox-2 expression during F9 and P19 differentiation. (A) F9 EC cells were induced to differentiate into parietal endoderm by exposing adherent cells to $10^{-1} \mu \mathrm{M}$ all-trans retinoic acid (RA) (nonaggregates) or into visceral endoderm by exposing cells grown in suspension to $10^{-1}$ $\mu \mathrm{M}$ RA (aggregates). P19 were treated with $1 \mu \mathrm{M}$ all-trans RA. Total RN A was extracted at day 0 (untreated F9 and P19 cells), day 1 and 2 of RA treatment. N orthern bl ot analyses were performed for OPN, Oct-4, and 28S rRNA probes. Each lane contains 10 and $30 \mu \mathrm{g}$ of total mRNA in F9 and P19 EC cells, respectively. The same filter was sequentially hybridized to OPN, Oct-4, and 28S rRNA probes. (B) EMSA of differentiating F9 and P19 EC cell extracts. Whole cell extracts at day 0 (untreated F9 and P19 EC cells), day 1 and 2 of RA treatment were incubated with the $\mathrm{O}$ and $\mathrm{S}$ oligonucleoti de used as probe. Complexes are denoted as follows: (4) Oct-4 monomer; (4/4) Oct-4 homodimer; (4/1) heterodimer of Oct-1 and Oct-4; (1) Oct-1 monomer; $(1 / *)$ Oct-1 homo- or heterodimer. PIO-1 complex in P19 EC cells could be observed only after longer exposure.

transient 2.5-fold increase in both Oct-4 and OPN mRN A levels was observed after 1 day of retinoic acid (RA) treatment regardl ess whether F9 EC cells were differentiating al ong visceral or parietal pathways (Fig. 7A, F9 lane 1 in each panel). Oct-4 and OPN mRN A levels decreased to undetectable levels after 2 days in RA (Fig. 7A, F9 lane 2 in each panel). Induction of Iaminin expression, used as a marker for parietal and visceral endoderm, was observed after 1 day of differentiation of F9 EC cells (data not shown). These results demonstrate a strict correlation between Oct-4 and OPN expression during differentiation of F9 EC. The profile of Oct-4 mRN A upand down-regulation is closely followed by OPN mRNA levels and recapitulates up- and down-regulation of these genes observed during the hypoblast formation.
Oct-4 and OPN expression was al so compared in RAtreated P19 EC cells, which were induced to differentiate al ong a neuronal pathway (Robertson 1987). In contrast to F9 EC cells, the level of Oct-4 and OPN transcripts were down-regulated immediately (Fig. 7A, P19). Therefore, the transient increase of OPN mRN A during F9 EC cell differentiation is not likely attributable to a direct effect of RA on OPN gene regulation.

The in vitro binding activities of Oct- 4 and Sox- 2 were compared with the OPN transcript levels during differentiation of F9 EC and P19 EC cel Is (Fig. 7B) to determine whether a correlation between factor binding and OPN expression could be established. Oct-4 monomer and dimer binding to the $\mathrm{O}$ oligonucleotide encoding the $\mathrm{i}$ opn site was not noticeably altered in $\mathrm{F} 9$ extracts prepared after 1 day of differentiation (Fig. 7B, right: F9, cf. lane 0 with lane 1). Extracts prepared after 2 days of differentiation showed similar monomer binding but had a marked reduction in Oct-4 dimer formation (Fig. 7B, left: F9, lane 2). In contrast, the level of Sox-2 decreased immediately after 1 day of differentiation (Fig. 7B, right: F9, lane 1) and only low levels of Sox-2 were detected after 2 days of RA treatment (Fig. 7B, right: F9, lane 2). These results suggest that transiently el evated OPN expression levels observed after 1 day of RA treatment may be attributable to the more rapid decl ine in Sox- 2 binding than in Oct-4 binding. Consequently, the inhibitory action of Sox-2 on Oct-4 in the i-opn fragment (above) is alleviated temporarily, resulting in higher levels of $\mathrm{i}$-opn activity in the brief interval before both factors are absent.

The level of Oct- 4 in P19 cells decreased to undetectable levels after 2 days of differentiation (Fig. 7B, left: P19). An additional complex detected at day 1 of RA treatment (Fig. 7B, left: P19, lane 1, mobility between 4 and 4/ 4 complex) may contain Brn-2 (Fuji i and Hamada 1993). In contrast to Oct-4, only a sl ight decline of Sox-2 levels was observed after 2 days of differentiation (Fig. 7B, left: P19), suggesting that the rapid decrease of Oct-4 protein levels might result in an immediate OPN downregulation.

\section{Discussion}

In this study we show that OPN is likely a direct target gene of Oct- 4 in cells of the mouse preimplantation embryo. Oct-4 is thought to play an important role in the establishment of hypoblast-derived cell layers (Palmieri et al. 1994) and OPN is a secreted phosphoprotein containing a RGD motif promoting adhesion and migration in various cell types (for review, see Denhardt and Guo 1993; Denhardt et al. 1995). We have demonstrated that Oct-4 is found in close association to a new EC-cellspecific enhancer of the OPN gene, i-opn, in the chromatin of EC cells. Furthermore, the activity of the i-opn enhancer in these cells depends on at least two transcription factors that are coexpressed in the preimplantation embryo, namely Oct-4 and Sox-2 (Rosner et al. 1990; Schöler et al. 1990b; R. Lovell-Badge, pers. comm.). Oct-4 binds as a dimer to a specific el ement, termed PORE, in 
the i-opn enhancer, and transactivates more strongly from this element than from the canonical octamer motif al one. Biochemical analysis of POU protein binding to mutated PORE elements indicates that the Oct-4/PORE complex provides a new paradigm for the interaction of POU proteins with DNA by using only the homeodomain core motifs for binding. Sox-2 also binds to the i-opn enhancer and represses transactivation by Oct-4 and other as yet unidentified factors. Sox-2-mediated repression in i-opn contrasts with Sox-2-mediated activation in the fgf-4 enhancer (Yuan et al. 1995). Sox-2-mediated repression and activation of Oct-4 function in these two enhancers depends on the carboxy-terminal region of Sox-2 (Yuan et al. 1995).

\section{Oct-4 dimer formation on the PORE}

The POU transcription factors contain a pair of closely and flexibly linked DNA-binding domains that, in principle, have numerous possible modes of interactions with substrate DNA. The POU $\mathrm{S}_{\mathrm{S}}$ and $\mathrm{POU}_{\mathrm{HD}}$ domains can be separated and bind DNA independently. However, mixing experiments demonstrate that the separated domains, as well as the linked domains, can bind cooperatively to appropriate DNA substrates (Klemm and Pabo 1996). Analysis of crystals containing POU protein-DNA complexes has revealed that the amino-terminal $\mathrm{POU}_{\mathrm{S}}$ domain is joined to the POU $\mathrm{HD}_{\mathrm{H}}$ domain by an unstructured linker that would allow each domain to dock onto DNA with few steric constraints imposed by the other domain (Klemm et al. 1994). The linker of Oct-4 is relatively short (17 amino acids) compared to those of other POU proteins (15-56 amino acids) and constrains the distance between and the relative orientation of two half sites for simultaneous binding. The crystal structure of the Oct-1 POU domain bound to the octamer sequence of the histone H2B promoter (Klemm

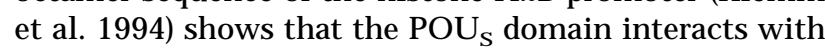
the $5^{\prime}$ ATGC portion of the octamer motif and the $\mathrm{POU}_{\mathrm{HD}}$ with the $3^{\prime} \mathrm{A} / \mathrm{T}$-rich portion. The two domains bind to opposite faces of the DNA helix and contact the same base pairs at the center of the octamer motif, but do not interact directly. The fact that $\mathrm{POU}_{\mathrm{S}}$ and $\mathrm{POU}_{\mathrm{HD}}$ bind the same base pairs, albeit at opposite sides, has been suggested to be important for mediating cooperative binding of $\mathrm{POU}_{\mathrm{S}}$ and $\mathrm{POU}_{\mathrm{HD}}$ through changes in the DNA structure (Klemm and Pabo 1996). According to the length and the conformational flexibility of the linker, it seems possible that binding of two more distantly spaced half sites by the two domains of a POU protein monomer occurs.

A second possibility is that the linker allows the POU protein to bind half sites in different orientations. This is demonstrated by the crystal structure of the Pit-1 POU domain on a palindromic recognition site (ATGTATATACAT; Jacobson et al. 1997). Although the protein folds of each of thetwo Pit-1 DN A-binding domains, and the docking onto DN A of each domain is very simiIar to that observed in the Oct-1 crystal, the relative orientation of the two domains in the two crystals is

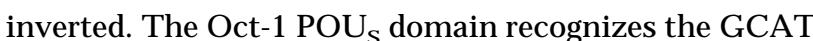

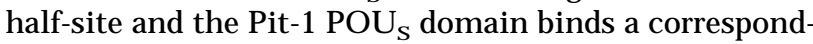
ing sequence GTAT. However, the latter motif lies on the opposite strand (schema in Fig. 8D). As a consequence, the orientation of $\mathrm{POU}$ s relative to $\mathrm{POU}_{\mathrm{HD}}$ is inverted.

Cooperative binding by domains of two different POU protein molecules provides a second fundamentally different mode of POU protein-DNA interaction. In the Pit-1 crystal, the repeat unit is a homodimer in which a dimerization interface is formed between the amino-terminal part of POU $\mathrm{HD}_{\mathrm{D}}$ helix 3 of one Pit-1 molecule and the amino-terminal end of $\mathrm{POU}_{\mathrm{S}}$ in the second molecule (helix 1 in conjunction with the loop between helices 3 and 4).

Our data show that in vitro Oct-4 also forms a homodimer on DNA. However, mutagenic analysis of the binding site (Fig. 5A,B) and computer modeling suggest that the Oct-4 dimer is different than the Pit-1 dimer (schema on Fig. 8D) and illustrates yet a third means by which POU proteins can interact with specific DNA sequences. In contrast to Pit-1, which requires the palindromic arrangement of ATGTAT without any spacing, the Oct-4 dimer requires a palindrome of ATTTG with an exact spacing of 5 nucleotides (Figs. 5B and 8D). The second half site of the PORE is contained in the octamer

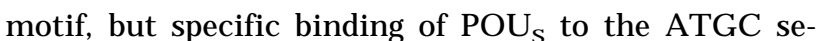
quence seems not to be required as shown by a mutational analysis (Fig. 5B,C). To determine the arrangement of both Oct-4 POU domains the sequence of Oct-4 POU domain was modeled into the coordinates of Oct-1 POU domain (Fig. 8A,B). Because the POU domains of Oct-1 and Oct-4 are extremely well conserved, it is likely that Oct-4 POU domain protein structure bound to DN A is similar to that of Oct-1 (Herr and Cleary 1995; Fig. 8C). This was done first for the octamer motif that overlaps with the second half site of the PORE and then extended to the other half site (Fig. 8A). The arrangement basi cally results from a point-symmetrical flipping of the first Oct-4 POU molecule with respect to the second. In case of Oct-4, the amino terminus of POU $\mathrm{HD}_{\mathrm{HD}}$ (nonhelical region between linker and helix 1 ) would interact with the carboxy-terminal part of $\mathrm{POU}_{\mathrm{S}}$ helix 1 and the loop between helices 1 and 2. Thus, dimerization of Oct-4 on the PORE likely represents a new paradigm for POU protein-DNA interaction.

According to this model, several side chains are pre dicted to interact with each other. The computer model of Oct-4 POU domain binding to the PORE predicts that Ile 21 of the $\mathrm{POU}_{\mathrm{S}}$ domain of one molecule is within $4 \AA$ of Ser-7 of the POU ${ }_{\mathrm{HD}}$ of the other molecule (Fig. $8 \mathrm{C}$, numbering of the POU domain according to Herr and Cleary 1995). Thus, the mol ecules would be in very close proximity at one position on each side of the dimer. Phosphorylation of Ser-7 in the Oct-1 POU ${ }_{\mathrm{HD}}$ inhibits binding to the octamer sequence in the H2B promoter (Segil et al. 1991). DN A binding is also reduced in case of Thr-7 phosphorylation of the Pit-1 POU $\mathrm{HD}_{\mathrm{H}}$, but the magnitude of the effect is dependent on the DN A sequence (Kapiloff et al. 1991; Caelles et al. 1995). Both Ser and 

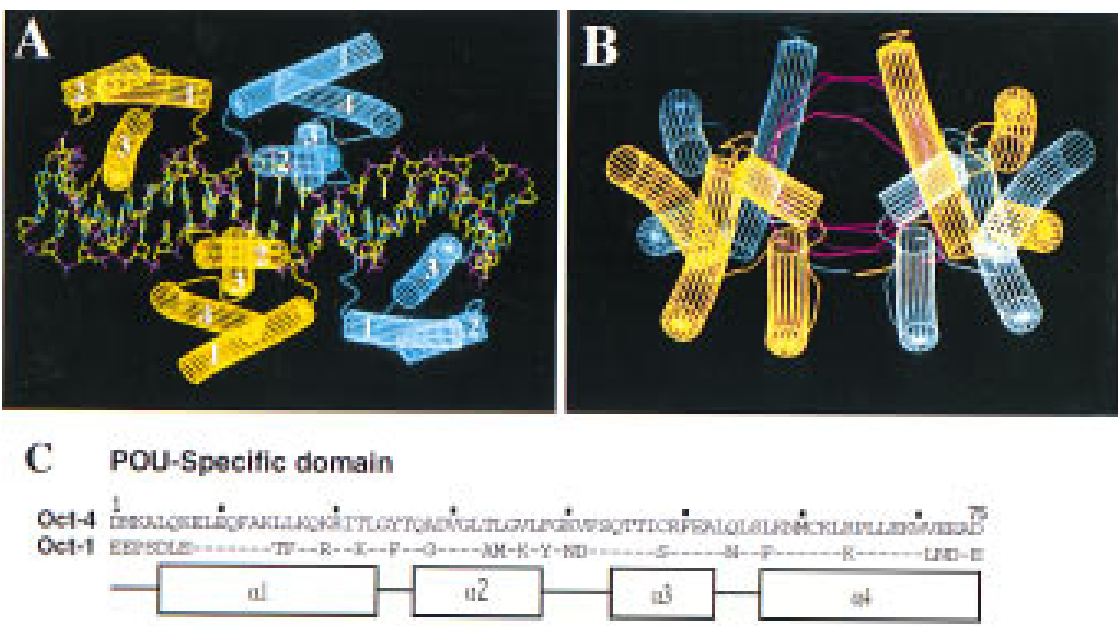

Linker

Oct-4 mancogr crastwon

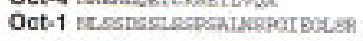

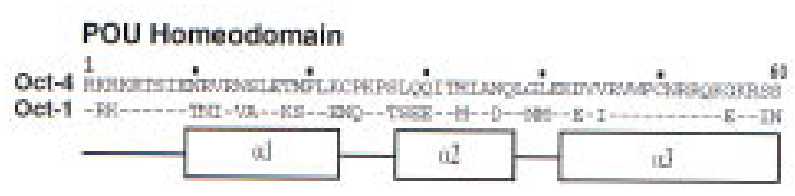

D

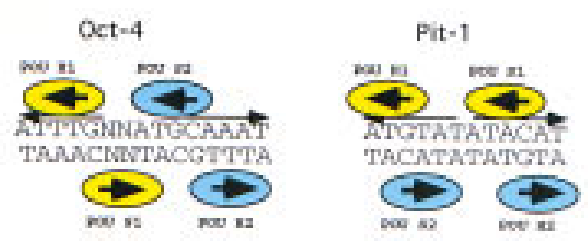

Thr residues can be phosphorylated in vitro by protein kinase A (Kapiloff et al. 1991; Segil et al. 1991) and in vivo by a cell-cycle-dependent kinases (Segil et al. 1991; Caelles et al. 1995). In the case of the Oct-4 dimer, phosphorylation of POU ${ }_{H D}$ Ser-7 should interfere with dimer formation on the PORE. Because Oct-1, Oct-2, and Oct-6 can also form a dimer on PORE (Fig. 5A; unpubl.), a reduction of dimer formation attributable to phosphorylation at position 7 of POU $\mathrm{HD}_{\mathrm{H}}$ could be generally valid for all POU factors. In contrast, phosphorylation at position 7 should not interfere with Pit-1 dimerization on the ATGTATATACAT sequence.

\section{Regulation of OPN by Oct-4 and Sox-2}

Our data show that a short fragment of i-opn contains DN A-binding sites for Oct-4 and Sox-2 in close proximity and is sufficient to drive expression of reporters in F9 EC cell lines. The intron fragment of OPN is enriched in $\alpha 4$ immunoprecipitates of cross-linked F9 EC cell chromatin. Because the F9 EC cell line shares many characteristics with cells of the preimplantation embryo, we have proposed that Oct-4 and Sox- 2 regulate expression of the OPN gene during preimplantation stages of embryogenesis by binding to specific DNA sequences in i-opn (Strickland and Mahdavi 1978; Strickland et al.

1980; Hogan et al. 1981). Oct-4 mRNA is expressed at comparable levels in cells of the morulae, in the ICM of blastocysts, and in the epiblast of day 5.5 and 6.5 embryo (Schöler et al. 1990a; Yeom et al. 1991). In contrast, OPN expression changes during these early stages of devel opment. Weak OPN expression is detected in the morulae (Fig. 3B). The highest expression level of OPN is observed in the ICM / hypoblast of day 4.0 and 4.5 blastocysts (Fig. 3B,C). After these stages, OPN is down-regulated (Fig. 3C). This could be attributable to additional transcription factors that interact with Oct-4 on the intron enhancer. Either a repressive or an activating cofactor could account for the relatively variable OPN expression during early embryonic development.

Sox-2 is one candidate for a modulator of Oct-4 transactivation. Sox-2 expression varies in different embryonic cell types, which correlates inversely with the expression pattern of OPN in these cells (Fig. 6A). In transient transfection assays, the PORE but not the octamer motif is active (Fig. 5D). The activity of the PORE region is increased two- to threefold when the Sox-binding site is included (Fig. 6B, cf. $6 \times 0$ and $6 \times 0$ ). However, this increase is not attributable to Sox- 2 because a 20 -fold activation was achieved when the Sox-2-binding site was mutated (Fig. 6B). Furthermore, cotransfection experiments in differentiated cells indicate that Sox-2 can re- 
press Oct-4-mediated i-opn activity in a dose-dependent manner (Fig. 6E). Repression requires Sox-2 binding to DN A and al so depends on the carboxy-terminal region of Sox-2 that has been described previously as a transactivation domain (Fig. 6F,H; Yuan et al. 1995). Repression of the i-opn enhancer by Sox-2 is in contrast to what has been shown for the fgf-4 3' enhancer, where Sox-2 stimulates Oct-4-mediated activity (Yuan et al. 1995).

Varying the level or activity of Sox-2 and Oct-4 in embryonal cells is likely to result in altered expression of genes such as fgf-4 and OPN. Changes in Oct-4, Sox-2, and OPN expression levels that occur during differentiation of F9 EC cells are consistent with the model of Oct-4 and Sox-2 interaction on i-opn that was established from binding and transactivation data. Sox-2 levels decline rapidly, whereas Oct-4 levels decline more slowly during F9 differentiation (Fig. 7B). Thus, Sox-2mediated repression of Oct-4 activation of $\mathrm{i}$-opn is relieved briefly, resulting in the transient increase of OPN expression (Fig. 7A). Forty-eight hours after RA treatment, Oct-4 is no longer expressed, leading to the loss of a complex at the PORE, which would likely result in Iow or undetectable levels of OPN mRNA production (Fig. 7A).

Sox-2 is not likely to be the only transcription factor involved in modulating the Oct-4-mediated transactivation of the intron enhancer. This would explain why the PORE/octamer region is much weaker than a fragment that is longer and contains a mutated Sox element (Fig. $6 \mathrm{~B}$, cf. $6 \times \mathrm{O}$ and $6 \times \mathrm{OS}$ ).

\section{Possible role of OPN in the preimplantation embryo}

The formation of the hypoblast and its derivatives, parietal and visceral endoderm, depends on interactions between the ECM and integrins (Behrendtsen et al. 1995). OPN binds to cells displaying the $\alpha_{v} \beta_{1}, \alpha_{v} \beta_{3}$, and $\alpha_{v} \beta_{5}$ integrins on their surface and contains a GRGDS amino acid motif that is absolutely required for the integrin interaction (for review, see Eble and Kühn 1997). Deletion of the $\beta_{1}$ integrin gene in mice results in ICM failure and peri-implantation lethal ity, indicating that $\beta_{1}$ integrin is required for preimplantation devel opment (Fässler and Meyer 1995; Stephens et al. 1995).

OPN may bind to integrins in a way that alters cellcell adhesion properties selectively. High levels of OPN expression in the 4.0-dpc ICM and forming hypoblast could result in the loosening of cell-cell and cell-ECM contacts. OPN-deficient embryos exhibit no apparent phenotype (Hynes 1996) suggesting that loss of OPN function during embryogenesis can be compensated by other ECM proteins. Bone sialoprotein II (BSP II) is one possible candidate. Further analyses will be done to define other genes that are also up-regulated transiently by Oct-4 in the developing hypoblast.

\section{Materials and methods}

Embryo collection, cell culture, and transient transfection

Morulae and blastocysts were flushed from CD1 mice in M2 medium as described in Hogan et al. (1994). COS, 3T 3, 293, and F9 EC cells were grown in Dulbecco's modified Eagle medium (DM EM ) supplemented with $10 \%$ fetal calf serum (FCS). P19 EC and GCLB cells were maintained in DM EM supplemented with $10 \%$ FCS and $1 \%$ nonessential amino acids (Seromed). MBL-1 ES cells were cultured in DM EM [0.45\% glucose (wt/ vol)], $15 \%$ FCS, $1 \mu \mathrm{M} \beta-\mathrm{ME}$, and in the presence of $1000 \mathrm{U} / \mathrm{ml}$ leukemia inhibitory factor (LIF, GIBCO-BRL). Murine EC and ES cells were grown on $0.1 \%$ gelatin-coated tissue culture plates. P19 EC cells were induced to differentiate by treatment with $1 \mu \mathrm{m}$ all-trans RA (Sigma). Differentiation of F9 cells into parietal endoderm was accomplished by adding $0.1 \mu \mathrm{M}$ RA to adherent cells. Differentiation of F9 cells into visceral endoderm was performed by growing the cells for $48 \mathrm{hr}$ in suspension using bacterial Petri dishes. Aggregates were transferred to tissue culture dishes allowing cells to attach to a surface for further growth. Medium containing RA was changed every $24 \mathrm{hr}$.

Cells were transfected using the calcium-phosphate precipitation method at a density of $3 \times 10^{5}$ cells per 6 -cm dish. Each dish received a total of $12 \mu \mathrm{g}$ of DNA including $10 \mu \mathrm{g}$ of luciferase reporter plasmid and $2 \mu \mathrm{g}$ of human $\beta$-actin-LacZ as internal standard. In cotransfection assays, $1 \mu \mathrm{g}$ of luciferase reporter plasmid and varied amounts of expression plasmids were used in combination with pBluescript KS (Stratagene) to bring the final DNA concentration to $12 \mu \mathrm{g}$. All experiments were carried out four times. After $40 \mathrm{hr}$ of transfection, cells were harvested and $50-\mu \mathrm{l}$ extracts were prepared in ice-cold $250 \mathrm{~mm}$ Tris (pH 7.8), 1 mm DTT. All luciferase activities were normalized by $\beta$-galactosidase expression levels.

\section{Plasmid constructions}

The i-opn and i-opn mut fragment were generated by PCR amplification of osteopontin intron 1 using $1 \mu \mathrm{g}$ of $\mathrm{F} 9$ genomic DNA, 5'-TATTAGTCCAAATAGAACATC-3' and 5'-TATTAGTCCAAATAGAACATCTTACTCAAATTCAAAGATATCTTTGTTTCTTTCAGCTTTGTATAATGTAAGTTAAAATCACATTGCACAAGCAAGCGG-3' as sense primer, respectively, and 5'-CTCTCATCCTTAGCAAGGAA-3' as antisense primer. The conditions were the same as described for PCR of immunoprecipitated cross-linked chromatin. The i-opn was precloned into the PCR II vector using the TA Cloning kit (Invitrogen). The i-opn was cut out of the PCR II vector by EcoRI and was recloned into the EcoRI site of pBluescript KS. After HindlII-BamHI digestion, the i-opn of pBluescript KS was cloned into HindIII-BamHI site of -37 tkluc (kindly provided by A. Hecht, ZMBH, Heidel berg, Germany). The $6 \times 0,10 \times 0$, $6 \times \mathrm{O}^{-1}, 6 \times \mathrm{O}^{-2}, 6 \times \mathrm{O}^{-3}, 6 \times \mathrm{O}^{-4}, 6 \times \mathrm{OS}, 6 \times \mathrm{O}^{-\mathrm{S}}$, and $6 \times \mathrm{OS}^{-}$ reporter plasmids were obtained by multimerizing the corresponding oligonucleotides. The $5^{\prime}$ overhang of the multimers were filled in using Klenow polymerase and fragments of 6 or 10 oligonucleotide repeats were precloned into the EcoRV site of pBluescript KS. The HindIII-BamHI fragment containing the oligonucleotide multimer was cut out of the pBluescript KS and was inserted into HindlII-BamHI sites of -37 tkluc.

\section{Labeling, cross-linking, and shearing chromatin}

Proteins were labeled by adding $175 \mu \mathrm{Ci} / \mathrm{ml}\left[{ }^{35}\right.$ S]methionine (labeling grade; Amersham) 1-2 hr before harvest. In vivo fixation of chromatin was done as described by Orlando and Paro (1993) with several modifications. Cells were removed from the plates by trypsin, resuspended at a density of $5 \times 10^{6} \mathrm{cells} / \mathrm{ml}$ in DMEM $/ 5 \%$ heat-inactivated FCS, and fixed in vivo by adding one-tenth volume of formal dehyde buffer [11\% formal dehyde ( $\mathrm{vol} / \mathrm{vol}$ ) in 10\% methanol, $0.1 \mathrm{M} \mathrm{N} \mathrm{aCl}, 1 \mathrm{~mm} \mathrm{Na-EDTA}, 0.5$ 
mM Na-EGTA (pH 8.0), $50 \mathrm{~mm}$ Tris- $\mathrm{HCl}(\mathrm{pH}$ 8.0)]. The fixation reaction was incubated $10 \mathrm{~min}$ at room temperature thoroughly mixed on ice for $40 \mathrm{~min}$, and stopped by adding glycine ( $125 \mathrm{~mm}$ final concentration). Fixed cells were collected by centrifugation $\left(500 \mathrm{~g}\right.$ for $10 \mathrm{~min}$ at $4^{\circ} \mathrm{C}$ ) and resuspended on a roller for 10 min at $4^{\circ} \mathrm{C}$ in $40 \mathrm{ml}$ Triton-washing buffer [0.25\% Triton X-100, $10 \mathrm{~mm} \mathrm{~N}$ a-EDTA, $0.5 \mathrm{~mm} \mathrm{~N}$ a-EGTA, $10 \mathrm{~mm}$ Tris- $\mathrm{HCl}$ (pH 8.0)] to lyse unfixed cells. Fixed chromatin was collected by centrifugation at $500 \mathrm{~g}$ for $10 \mathrm{~min}$ at $4^{\circ} \mathrm{C}$, washed in $40 \mathrm{ml}$ of $\mathrm{NaCl}$ washing buffer [200 mM NaCl, $1 \mathrm{~mm} \mathrm{Na-EDTA}, 0.5 \mathrm{~mm} \mathrm{Na}$ EGTA, $10 \mathrm{~mm}$ Tris- $\mathrm{HCl}(\mathrm{pH} \mathrm{8.0)})$ for $10 \mathrm{~min}$ at $4^{\circ} \mathrm{C}$, centrifuged again, resuspended in 2-3 $\mathrm{ml}$ of TE-EGTA buffer [1 $\mathrm{mm} \mathrm{Na-}$ EDTA, $0.5 \mathrm{~mm} \mathrm{~N}$ a-EGTA, $10 \mathrm{~mm}$ Tris- $\mathrm{HCl}(\mathrm{pH}$ 8.0)], transferred to siliconized Corex-glass tubes, and $\sim 0.5 \mathrm{ml}$ of glass microbeads (diameter of $0.10-0.11 \mathrm{~mm}$; B. Braun Biotech International) were added to every $3 \mathrm{ml}$ of cell suspension. The mixture was sonified on ice for $15 \mathrm{~min}$ with the Branson model B15 at a "duty cycle" of $0.65 \%$ with the output control set at 7-7.5 to produce DNA fragments of an average size of $500 \mathrm{bp}$, with a maximum size of $2.5 \mathrm{~kb}$. Samples were adjusted to $0.5 \%$ Sarkosyl and gently swirled for $10 \mathrm{~min}$ at room temperature. Cell debris was eliminated by two 15 -min centrifugation steps at $15,000 \mathrm{~g}$ at $4^{\circ} \mathrm{C}$.

Purification, immunoprecipitation, and decross-linking of fixed chromatin fragments

Cross-linked chromatin complexes were separated from free proteins, DNA, and RNA by $\mathrm{CsCl}$ isopyknic centrifugation. Samples were adjusted to $1.42 \mathrm{gram} / \mathrm{ml} \mathrm{CsCl}$, brought to $5 \mathrm{ml}$ with the TE-EGTA-Sarkosyl buffer, and centrifuged in a Beckman SW55T i rotor at $40,000 \mathrm{rpm}$ for $72 \mathrm{hr}$ at $20^{\circ} \mathrm{C}$. Fractions of $300 \mu \mathrm{l}$ were collected from the bottom of the gradient using a $0.25-\mathrm{mm}$ capillary needle and ${ }^{35} \mathrm{~S}$ content was measured in a Beckman LS 6000 SC scintillation counter. Fractions containing the cross-linked chromatin $(\sim 1.38 \mathrm{gram} / \mathrm{ml})$ were pooled and dialyzed overnight at $4^{\circ} \mathrm{C}$ against $5 \%$ glycerol, $1 \mathrm{~mm} \mathrm{Na}$ EDTA, $0.5 \mathrm{~mm} \mathrm{~N}$ a-EGTA, $10 \mathrm{~mm}$ Tris- $\mathrm{HCl}$ (pH 8.0). Fixed chromatin can be stored in this buffer for at least 3 months at $-80^{\circ} \mathrm{C}$ and small aliquots were used for immunoprecipitations.

Aliquots $(200 \mu \mathrm{g}$ of cross-linked chromatin in $100 \mu \mathrm{l})$ were cleared by centrifugation ( $15 \mathrm{~min}$ at $13,000 \mathrm{rpm}$ ), mixed with 30 $\mu \mathrm{H}_{2} \mathrm{O}$ and $100 \mu \mathrm{l} 2 \times$ TE-EGTA buffer, carefully adjusted to $0.1 \% \mathrm{SDS}$ (wt/vol) and $0.5 \mathrm{M} \mathrm{N} \mathrm{aCl}$, incubated for $5 \mathrm{~min}$ at room temperature, adjusted to $1 \%$ Triton X-100 (wt/vol), $0.1 \% \mathrm{Na}$ Deoxycholate and $0.1 \%$ BSA, incubated for $10 \mathrm{~min}$, and cleared again by centrifugation for $15 \mathrm{~min}$ at $13,000 \mathrm{rpm}$. As a preclearing step, supernatants were incubated with $100 \mu \mathrm{l}$ of Dynabeads coupled to sheep anti-rabbit IgG $\left(6 \times 10^{8}\right.$ to $7 \times 10^{8}$ beads $/ \mathrm{ml}$; Dynal) for $1 \mathrm{hr}$. Supernatants were removed from beads by a magnetic particle concentrator (M PC; Dynal) and $10 \mu \mathrm{g}$ of specific antibodies against Oct-4 (or IgG of preimmune serum) were added. Samples were rotated for $3 \mathrm{hr}$ at $4^{\circ} \mathrm{C}, 300 \mu \mathrm{l}$ of sheep anti-rabbit IgG Dynabeads added, incubated with rotation for 2 $\mathrm{hr}$ at $4^{\circ} \mathrm{C}$, and immunocomplexes were pelleted by magnetic field. Pellets were washed ( $10 \mathrm{~min}$ per wash) five times in $1 \mathrm{ml}$ of washing buffer [1\% Triton X-100 (wt/ vol), 0.1\% N a-deoxycholate (wt/vol), $0.1 \%$ SDS (wt/vol), 0.1\% BSA (wt/vol), $0.5 \mathrm{~m}$ $\mathrm{NaCl}, 1 \mathrm{~mm} \mathrm{Na}$-EDTA, $0.5 \mathrm{~mm} \mathrm{~N}$ a-EGTA, $10 \mathrm{~mm}$ Tris- $\mathrm{HCl}(\mathrm{pH}$ 8.0)], once with $1 \mathrm{ml}$ of $\mathrm{LiCl}$-washing buffer [ $250 \mathrm{~mm} \mathrm{LiCl}, 0.5 \%$ NP-40 (wt/vol), 0.5\% Na-deoxycholate (wt/vol), $1 \mathrm{~mm} \mathrm{Na-}$ EDTA, $0.5 \mathrm{~mm} \mathrm{~N}$ a-EGTA, $10 \mathrm{~mm}$ Tris- $\mathrm{HCl}$ (pH 8.0)], twice with $1 \mathrm{ml}$ of TE-EGTA buffer, and resuspended in $350 \mu \mathrm{l}$ of TEEGTA buffer. One hundred microliters were kept for protein analysis, and $250 \mu \mathrm{l}$ was treated $30 \mathrm{~min}$ at $37^{\circ} \mathrm{C}$ with DN ase- free RN ase $A(50 \mu \mathrm{g} / \mathrm{ml})$ and incubated overnight at $37^{\circ} \mathrm{C}$ in 250 $\mu \mathrm{g} / \mathrm{ml}$ proteinase $\mathrm{K} / 0.25 \%$ SDS.

\section{PCR on immunoprecipitated cross-linked chromatin}

PCR amplification was performed in a final volume of $100 \mu \mathrm{l}$, using $1 \mathrm{ng}$ of genomic F9 DNA or $1 \mathrm{ng}$ of immunoprecipitated cross-linked chromatin as template, 10 pmoles of each primer, $2.5 \mathrm{~mm}$ dNTPs (Pharmacia), 2.5 units of Taq DNA polymerase (Perkin Elmer-Cetus); and 1×PCR buffer (Perkin Elmer-Cetus). The PCR consisted of $30 \mathrm{cycles}$ of $1 \mathrm{~min}$ at $94^{\circ} \mathrm{C}, 1 \mathrm{~min}$ at $55^{\circ} \mathrm{C}$, and $1 \mathrm{~min}$ at $72^{\circ} \mathrm{C}$. Upstream and downstream primers pairs were as follows: OPN intron 1, 5'-CAAATTCAAAGATATCTTTGTTTC-3', 5'-CCCCACTATCTGATGTCTCT-3'; OPN exon 7, 5'-ATCCTGATGCCACAGATGAG-3', 5'-ACTTGTGGCTCTGATGTTCC-3'; G6PD fragment, 5'-AAGCCAAACTAGCAGCTAGG-3', 5'-GGGCTAGTCTATCATTGCAG-3'.

Preparation of protein extracts and EMSA

Extraction of proteins and EM SA conditions used for Oct-4 and Sox-2-binding anal ysis were carried out as described in Sylvester and Schöler (1994) and Dailey et al. (1994), respectively.

Oligonucleotides used in this study

Bold indicates introduced mutation, lowercase letters indicates non-OPN sequences. $\mathbf{0}, 5^{\prime}$-ctgaAAGTTAAAATCACATTTGAAATGCAAATGGAAAAGC aagtcga-3'; $\mathbf{0}^{\mathbf{- 1}}$, 5'-ctgaAAGTTAAAATCACATTTGAAA GG CAAATGGAAAA G Caagtcga3'; $\mathbf{0}^{-2}, 5^{\prime}$-ctgaAAGTTAAAATCACATGTGAAA GGCAAATGGAAAA G Caagtcga-3'; $\mathbf{0}^{-3}, 5^{\prime}$-ctgaAAGTTAAAATCACATGTGAAAT GCAAAT GGAAAA G Caagtcga-3'; $\mathbf{0}^{-4}, 5^{\prime}$-ctgaAAGTTAAAATCACATTTGAAATGCAACTGGAAAA G Caagtcga-3'; OS, 5'-ctgaTCTTTGTTTCTTTCAGCTTTGTATAATGTAAGTTAAAATCACATTTGAAATGCAAATGGAAAAGCaagtcga-3'; O-S, 5'-ctgaTCTTTGTTTCTTTCAGCTTTGTATAATGTAAGTTAAAATCACATTTGAAATGCAACTGGAAAAGCaagtcga-3'; OS $_{\mathbf{a}}^{-}$, 5'-ctgaT GCACTGACCTTTCAGCTTTGTATAATGTAAGTTAAAATCACATTTGAAATGCA-

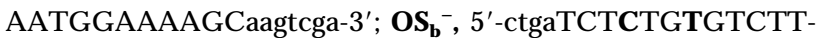
TCAGCTTTGTATAATGTAAGTTAAAATCACATTTGAAATGCAAATGGAAAAGC aagtcga-3'; P-1, 5'-ctgaAAGTTAAAATCACATTTGAATGCAAATGGAAAAGCaagtcga-3'; $\mathbf{P}+\mathbf{1}$, 5'-ctgaAAGTTAAAATCACATTTGATAATGCAAATGGAAAAGCaagtcga-3'.

\section{RNA extraction and Northern blot analyses}

Poly $(A)^{+}$RN A was isolated from cell lines using the Oligotex mRNA kit (Qiagen). Total cellular RNA was prepared by the guanidinium thiocyanate-phenol extraction procedure described in Chomczynski and Sacchi (1987). N orthern blot analysis of poly $(\mathrm{A})^{+}$and total RN A was performed as described elsewhere (Kroczek 1993). Hybond- $\mathrm{N}^{+}$filters (Amersham) were hybridized using a Pstl-Pstl Oct-4 probe (400-bp fragment corresponding to the $5^{\prime}$ end of the cDN A) $\left(10^{6} \mathrm{cpm} / \mathrm{ml}\right)$, a HindIII-HindlII OPN probe (position +157 to +1144 of the CDNA) $\left(2 \times 10^{6} \mathrm{cpm} / \mathrm{ml}\right)$ (2AR plasmid, kindly provided by $\mathrm{D}$. Denhardt, Rutgers University, Piscataway, $\mathrm{NJ}$ ), or an oligonucleotide 28 S probe: 5'-CAGCGAGCCGGGCTTCTTACCCATTTAAAGTTTGAGAATAGGTGGAGATCG-3' $\left(0.5 \times 10^{6} \mathrm{cpm} /\right.$ $\mathrm{ml}$; kindly provided M. Muckenthaler, EMBL). N orthern blots were analyzed for band intensity using the Phosphorlmager (Molecular Dynamics). 
RNA isolation from preimplantation embryos and RT-PCR

Ten embryos were suspended in $200 \mu$ of RNAzol (Tel-test, Inc.) and $20 \mu$ of chloroform while on ice by shaking. The suspension was left on ice $5 \mathrm{~min}$ and cleared by centrifugation $\left(12,000 \mathrm{~g}\right.$ for $15 \mathrm{~min}$ at $\left.4^{\circ} \mathrm{C}\right)$, and total RN A was precipitated for $15 \mathrm{~min}$ on ice after adding 1 volume of isopropanol and $2 \mu \mathrm{l}$ of glycogen (Boehringer $\mathrm{M}$ annhei $\mathrm{m} ; 20 \mathrm{mg} / \mathrm{ml}$ stock), collected by centrifugation $\left(12,000 \mathrm{~g}\right.$ for $15 \mathrm{~min}$ at $\left.4^{\circ} \mathrm{C}\right)$, washed with $70 \%$ ethanol, and dissolved in $11 \mu \mathrm{l}$ of DEPC- $\mathrm{H}_{2} \mathrm{O}$. Reverse transcription was performed for $1 \mathrm{hr}$ at $37^{\circ} \mathrm{C}$ in a total volume of 20 $\mu \mathrm{l}$ by adding $9 \mu \mathrm{l}$ of the following mix to the dissolved RN A: 0.5 $\mu \mathrm{g}$ of oligo(dT) (Promega), 39 units of RN asin (Promega), $1 \mathrm{~mm}$ dNTPs (Pharmacia), $1 \times$ RT -buffer, and 200 units of reverse transcriptase (M-MLV; Promega). PCR was performed using $5 \mu \mathrm{l}$ of the $\mathrm{RT}$ reaction as template for a $25 \mu \mathrm{l}$ final reaction volume. Each reaction contained: 10 pmoles of each primer, $2.5 \mathrm{~mm}$ dNTPs, 2.5 units of Taq polymerase (Perkin Elmer-Cetus), and $1 \times$ PCR buffer (Boehringer M annheim). The PCR consisted of 35 cycles of $30 \mathrm{sec}$ at $94^{\circ} \mathrm{C}, 1 \mathrm{~min}$ at $62^{\circ} \mathrm{C}$, and $1 \mathrm{~min}$ at $72^{\circ} \mathrm{C}$. U pstream and downstream primers were as follows: Oct-4, $5^{\prime}$ GGCGTTCTCTTTGGAAAGGTGTTC-3' and 5'-CTCGAACCACATCСТTCTCT-3' (spanning exons 2-3 and 4-5, respectively); OPN , 5'-GCAGACACTTTCACTCCAATCG-3' and 5'GCCCTTTCCGTTGTTGTCCTG-3' (located in exon 6 and exon 7 , respectively).

Riboprobe synthesis and whole mount in situ hybridization of 3.5-6.5 dpc embryos

The 1-kb OPN cDNA cloned in pGEM 3 (2AR plasmid) was excised with Hindlll from the vector and recloned in the same vector so that both orientations were available from the same promoter. Vectors were linearized with EcoRI, both sense and antisense riboprobes were generated by SP6 RNA polymerase and DIG-labeling mix according to the manufacturer (Boehringer $M$ annheim), reactions were digested with $\mathrm{RN}$ ase-free DN ase I (Promega) for $15 \mathrm{~min}$ at $37^{\circ} \mathrm{C}$, ethanol precipitated in the presence of $4 \mathrm{M} \mathrm{LiCl}$, and resuspended in DEPC $-\mathrm{H}_{2} \mathrm{O}$. The concentration and labeling efficiency of the probes were determined empirically by agarose gel el ectrophoresis and by dot-bl ot analyses, respectively.

In situ hybridization of embryos was performed as described by M acPhee et al . (1994) and Rosen and Beddington (1993), with some modifications. Embryos were fixed for $3 \mathrm{hr}$ in 3\% paraformal dehyde/ $0.5 \%$ glutaral dehyde in PBS, washed in PBS, permeabilized for $20 \mathrm{~min}$ at $4^{\circ} \mathrm{C}$ in PBT (PBS with $0.1 \%$ Triton $X-100)$, digested $15 \mathrm{~min}$ with proteinase $\mathrm{K}(1 \mu \mathrm{g} / \mathrm{ml}$ in PBT $)$, washed twice for $5 \mathrm{~min}$ in fresh glycine $(2 \mathrm{mg} / \mathrm{ml} \mathrm{PBT})$, refixed for $30 \mathrm{~min}$ in $4 \%$ paraformaldehyde/ $0.2 \%$ glutaral dehyde in PBS, briefly washed in triethanolamine buffer ( $100 \mathrm{~mm}, \mathrm{pH}$ 8.0) (Sigma), treated three times for 5 min with $0.25 \%$ acetic anhydride (Sigma) in triethanolamine buffer and once for $20 \mathrm{~min}$ with $0.1 \%$ sodium borohydride (Sigma) in PBT. After prehybridization in $50 \%$ formamide, $0.75 \mathrm{M} \mathrm{N} \mathrm{aCl}, 10 \mathrm{mM}$ Pipes (pH 6.8), $1 \mathrm{~mm}$ EDTA, $100 \mathrm{mg} / \mathrm{ml}$ yeast tRN A, 0.1\% BSA, $1 \%$ SDS for 2 $\mathrm{hr}$ at $50^{\circ} \mathrm{C}$, embryos were hybridized for $34 \mathrm{hr}$ in the same solution containing $1 \mu \mathrm{g} / \mathrm{ml}$ riboprobe. Embryos were rinsed briefly and washed extensively $\left(20 \mathrm{hr}\right.$ at $\left.60^{\circ} \mathrm{C}\right)$ in washing buffer 1 [300 mM N aCl, 1\% SDS in PE buffer (10 mM PIPES at pH 6.8, $1 \mathrm{~mm}$ EDTA], washed two times for $30 \mathrm{~min}$ in washing buffer 2 ( $50 \mathrm{~mm} \mathrm{NaCl}, 0.1 \%$ SDS in PE buffer), and incubated once for 30 min at $37^{\circ} \mathrm{C}$ with $100 \mu \mathrm{g} / \mathrm{ml}$ RN ase A diluted in the appropriate buffer [500 mM N aCl, $10 \mathrm{~mm}$ PIPES (pH 7.2), 0.1\% Triton X100]. Embryos were then washed for $45 \mathrm{~min}$ at $50^{\circ} \mathrm{C}$ in washing buffer 3 (50\% formamide, $300 \mathrm{~mm} \mathrm{~N} \mathrm{aCl}, 1 \%$ SDS in PE buffer), for $30 \mathrm{~min}$ at $50^{\circ} \mathrm{C}$ in washing buffer $4(50 \%$ formamide, $150 \mathrm{~mm}$ $\mathrm{NaCl}, 0.1 \%$ Triton X-100 in PE buffer), and finally $30 \mathrm{~min}$ followed by $20 \mathrm{~min}$ in washing buffer $5(500 \mathrm{~mm} \mathrm{NaCl}, 0.1 \%$ Triton X-100 in PE buffer) at $70^{\circ} \mathrm{C}$. Embryos were blocked for $1 \mathrm{hr}$ at room temperature in maleic acid washing buffer [100 mM maleic acid, $150 \mathrm{~mm} \mathrm{NaCl}(\mathrm{pH} 7.5)$ ] containing $2 \%$ heat-inactivated sheep serum and $2 \%$ blocking buffer (Boehringer $M$ annheim, cat. no. 1175041) and incubated overnight at $4^{\circ} \mathrm{C}$ with anti-digoxigenin Fab-alkaline phosphatase conjugate antibody (Boehringer $\mathrm{M}$ annheim) diluted 1:2000. Excess antibody was removed by washing the embryos three times for $5 \mathrm{~min}$ and then four times for $30 \mathrm{~min}$ with $1 \times$ TBST at room temperature. Embryos were then equilibrated in al kal ine phosphatase buffer [100 $\mathrm{mm} \mathrm{N} \mathrm{aCl}, 50 \mathrm{~mm} \mathrm{M} \mathrm{gCl}$, 0.1\% Tween-20, $100 \mathrm{~mm}$ Tris (pH 9.5)] and stained at room temperature in the dark with BM purple (Boehringer Mannheim, cat no. 1442074). Color reaction was stopped by washing the embryos with PBS. Uteri from 5.5 and $6.5 \mathrm{dpc}$ pregnant females were fixed with $4 \%$ paraformal dehyde, dehydrated and embedded in paraffin wax. Sections of $6 \mu \mathrm{m}$ were transferred to silone-coated slides. Treatment of the slides and hybridization were performed using the components and the protocol of N ovagen (SureSitell system). After several washing steps, the slides were blocked and incubated overnight at $4^{\circ} \mathrm{C}$ with 1:500 anti-DIG in blocking buffer. Slides were washed four times for 30 min each with mal eic acid washing buffer and stained with BM purple.

\section{Computer searches and modeling}

Identification of genes containing combination of octamer and Sox binding motifs was performed using the prepGCG program, findpatterns, and GenBank/EMBL database.

Homology modeling of Oct-4 dimer configuration was based on Oct-1 as template structure (Klemm et al. 1994). Modeling was performed using WHAT IF programme (Vriend 1990) and modeling protocol was used as described in Vriend and Eijsink (1993). There is no structure template available for the amino terminus, carboxyl terminus, and linker. For this reason, these parts of the molecule are not represented on the model.

The DNA was model ed by maintaining the phosphate and the sugar backbone of the DNA in the Oct-1 template structure. The bases were replaced using the corresponding bases found in the PORE DNA and were modeled to fall in the same plane as the corresponding Oct-1 bases with ideal geometry.

The Oct-4 dimer was constructed by optimaly superposing the GCAAAT sequence of the octamer motif on which Oct-4 was modeled, onto the AGTTTA sequence. The RMS deviation of the DNA superposition is $\sim 1.3 \AA$, which implies an uncertainty in the overall location of the second Oct- 4 with respect to the first Oct- 4 of $\sim 1-12 \AA$. The average local coordinate error is expected to be $\sim 1.5 \AA$ (Chinea et al. 1995).

\section{Acknowledgments}

We are most grateful to Drs. V. Orlando and R. Paro for a thorough introduction to and sound advice on the chromatin precipitation procedures. We thank Dr. L. Dailey for Sox-2 expression vectors and antibodies, Dr. L. Toldo for computer search, $M$. Pesce for reading the manuscript, and U. Schibler for a valuable comment. We also thank K. Hübner for Oct-4 protein and antibody, C. Sandberg for RNA purification. H.H. was supported by the Deutsche Studienstiftung and Fond der chemischen Industrie, K.A., V.B., and M.K.G. by the European Community (EU contracts CT92-0073 and BIO4-CT95-0284), G.F. by the CNRS. 
The publication costs of this article were defrayed in part by payment of page charges. This article must therefore be hereby marked "advertisement" in accordance with 18 USC section 1734 solely to indicate this fact.

\section{References}

Adamson, E.D. 1986. Cell-lineage-specific gene expression in development. In Experimental approaches to mammalian embryonic development (ed. J. Rossant and R.A. Pederson), pp. 321-364. Cambridge University Press, Cambridge, UK.

A mbrosetti, D.C., C. Basilico, and L. Dailey. 1997. Synergistic activation of the fibroblast growth factor 4 enhancer by Sox 2 and Oct-3 depends on protein-protein interactions facilitated by a specific spatial arrangement of factor binding sites. Mol. Cell Biol. 17: 6321-6329.

Behrendtsen, O., C.M. Alexander, and Z. Werb. 1995. Cooperative interactions between extracellular matrix, integrins and parathyroid hormone-rel ated peptide regulate parietal endoderm differentiation in mouse embryos. Development 121: 4137-4148.

Caelles, C., H. Hennemann, and M. Karin. 1995. M-phase-specific phosphorylation of the POU transcription factor GHF-1 by a cell cycle-regulated protein kinase inhibits DNA binding. Mol. Cell. Biol. 15: 6694-6701.

Chinea, G., G. Padron, R.W. Hooft, C. Sander, and G. Vriend. 1995. The use of position-specific rotamers in model building by homology. Proteins 23: 415-421.

Chomczynski, P. and N. Sacchi. 1987. Single-step method of RNA isolation by acid guanidinium thiocyanate phenol chloroform extraction. A nal. Biochem. 162: 156-159.

Collignon, J., S. Sockanathan, A. Hacker, M. Cohen-Tannoudji, D. N orris, S. Rastan, M. Stevanovic, P.N. Goodfellow, and R. Lovell-Badge. 1996. A comparison of the properties of Sox-3 with Sry and two related genes, Sox-1 and Sox-2. Development 122: 509-520.

Curatola, A.M. and C. Basilico. 1990. Expression of the K-fgf proto-oncogene is controlled by $3^{\prime}$ regulatory elements which are specific for embryonal carcinoma cells. Mol. Cell. Biol. 10: 2475-2484.

Dailey, L., H. Yuan, and C. Basilico. 1994. Interaction between a novel F9-specific factor and octamer-binding proteins is required for cell-type-restricted activity of the fibroblast growth factor 4 enhancer. Mol. Cell. Biol. 14: 7758-7769.

Denhardt, D.T. and X. Guo. 1993. Osteopontin: A protein with diverse functions. FASEB J. 7: 1475-1482.

Denhardt, D.T., W.T. Butler, A.F. Chambers, and D.R. Senger. 1995. Gene expression and phosphorylation of mouse osteopontin. In Osteopontin: Role in cell signaling and adhesion (ed. D.T. Denhardt, W.T. Butler, A.F. Chambers, and D.R. Senger). The N ew York Academy of Sciences, N ew York, NY.

Eble, J.A. and K. Kühn. 1997. In Integrin-ligand interaction (ed. J.A. Eble and K. Kühn). Springer-Verlag, Heidelberg, Germany.

Fässler, R. and M. Meyer. 1995. Consequences of lack of $\beta 1$ integrin gene expression in mice. Genes \& Dev. 9: 18961908.

Feldman, B., W. Poueymirou, V.E. Papaioannou, T.M. DeChiara, and M. Goldfarb. 1995. Requirement of FGF-4 for postimplantation mouse development. Science 267: 246249.

Ferrari, S., V.R. Harley, A. Pontiggia, P.N. Goodfellow, R. Lovell-Badge, and M.E. Bianchi. 1992. SRY, like HM G 1, recognizes sharp angles in DNA. EMBO J. 11: 4497-4506.

Fujii, H. and H. Hamada. 1993. A CN S-specific POU transcrip- tion factor, Brn-2, is required for establishing mammalian neural cell lineages. Neuron 11: 1197-1206.

Gardner, R.L. 1983. Origin and differentiation of extraembryonic tissues in the mouse. Int. Rev. Exp. Pathol. 24: 63-133.

Giese, K., J. Cox, and R. Grosscheld. 1992. The HM G domain of Iymphoid enhancer factor 1 bends DNA and facilitates assembly of functional nucleoprotein structures. Cell 69: 185195.

Herr, W. and M.A. Cleary. 1995. The POU domain: Versatility in transcriptional regulation by a flexible two-in-one DNAbinding domain. Genes \& Dev. 9: 1679-1693.

Hogan, B.L.M., A. Taylor, and E. Adamson. 1981. Cell interactions modulate embryonal carcinoma cell differentiation into parietal and visceral endoderm. Nature 291: 235-237.

Hogan, B.L.M., R. Beddington, F. Constantini, and E. Lacy. 1994. Section I: In vitro culture of eggs, embryos, primordial sperm cells and teratocarcinoma cells. In Manipulating the mouse embryo. A laboratory manual (ed. B.L.M. Hogan, R. Beddington, F. Constantini, and E. Lacy), 2nd ed., p. 386. Cold Spring Harbor Laboratory Press, Cold Spring Harbor, NY.

Hynes, R.O. 1996. Targetes mutations in cell adhesion genes: What have we learned from them? Dev. Biol. 180: 402-412.

Jacobson, E.M., P. Li, A. Leon-del-Rio, M.G. Rosenfeld, and A.K. Aggarwal. 1997. Structure of Pit-1 POU domain bound to DNA as a dimer: Unexpected arrangement and flexibility. Genes \& Dev. 11: 198-212.

Kapiloff, M.S., Y. Farkash, M. Wegner, and M.G. Rosenfeld. 1991. Variable effects of phosphorylation of Pit-1 dictated by the DN A response elements. Science 253: 786-789.

Klemm, J.D. and C.O. Pabo. 1996. Oct-1 POU domain-DNA interactions: Cooperative binding of isolated subdomains and effects of covalent linkage. Genes \& Dev. 10: 27-36.

Klemm, J.D., M.A. Rould, R. Aurora, W. Herr, and C.O. Pabo. 1994. Crystal structure of the Oct-1 POU domain bound to an octamer site: DNA recognition with tethered DNA-binding modules. Cell 77: 21-32.

Kraft, H.J., S. M ossel man, H.A. Smits, P. Hohenstein, E. Piek, Q. Chen, K. Artzt, and E.J. van Zoelen. 1996. Oct-4 regulates alternative platelet-derived growth factor alpha receptor gene promoter in human embryonal carcinoma cells. J. Biol. Chem. 271: 12873-12878.

Kroczek, R.A. 1993. Southern and N orthern analysis. J. Chromatogr. 618: 133-145.

Leger, H., E. Sock, K. Renner, F. Grummt, and M. Wegner. 1995. Functional interaction between the POU domain protein Tst-1/Oct-6 and the high-mobility-group protein HM G-I/Y. Mol. Cell. Biol. 15: 3738-3747.

Liu, L. and R.M. Roberts. 1996. Silencing of the gene for the beta subunit of human gonadotropin by the embryonic transcription factor Oct 3/4. J. Biol. Chem. 271: 16683-16689.

MacPhee, D.J., K.J. Barr, P.A. De Sousa, S.D. Todd, and G.M. Kidder. 1994. Regulation of $\mathrm{Na+}, \mathrm{K}(+)-A T$ Pase al pha subunit gene expression during mouse preimplantation development. Dev. Biol. 162: 259-266.

N adijcka, M. and N. Hillman. 1974. Ultrastructural studies of the mouse blastocyst substages. J. Embryol. Exp. Morphol. 32: 675-695.

Niswander, L. and G.R. Martin. 1992. Fgf-4 expression during gastrulation, myogenesis, limb and tooth development in the mouse. Development 114: 755-768.

Nomura, S., A.J. Wills, D.R. Edwards, J.K. Heath, and B.L. Hogan. 1988. Developmental expression of 2ar (osteopontin) and SPARC (osteonectin) RN A as reveal ed by in situ hybridization. J. Cell. Biol. 106: 441-450.

Okamoto, K., H. Okazawa, A. Okuda, M. Sakai, M. M uramatsu, 
and H. Hamada. 1990. A novel octamer binding transcription factor is differentially expressed in mouse embryonic cells. Cell 60: 461-472.

Orlando, V. and R. Paro. 1993. Mapping Polycomb-repressed domains in the bithorax complex using in vivo formal dehyde cross-linked chromatin. Cell 75: 1187-1198.

Palmieri, S.L., W. Peter, H. Hess, and H.R. Schöler. 1994. Oct-4 transcription factor is differentially expressed in the mouse embryo during establishment of the first two extraembryonic cell lineages involved in implantation. Dev. Biol. 166: 259-267.

Pesce, M., X. Wang, D.J. Wolgemuth, and H.R. Schöler. 1998a. Differential expression of the Oct-4 transcription factor during mouse germ cell differentiation. Mech. Dev. 71: 89-98.

Pesce, M., M.K. Gross, and H.R. Schöler. 1998b. In line with our ancestors: Oct- 4 and the mammalian germ. BioEssays (in press).

Pruitt, S.C. 1994. Primitive streak mesoderm-like cell lines expressing Pax-3 and Hox gene autoinducing activities. Development 120: 37-47.

Rizzino, A. and E. Rosfjord. 1994. Transcriptional regulation of the murine k-fgf gene. Mol. Reprod. Dev. 39: 106-111.

Robertson, E. 1987. Cell culture methods and induction of differentiation of embryonal carcinoma. In Teratocarcinomas and embryonic stem cells. A practical approach, pp. 19-50. IRL Press, Oxford, UK.

Rosen, B. and R.S. Beddington. 1993. Whole-mount in situ hybridization in the mouse embryo: Gene expression in three dimensions. Trends Genet. 9: 162-167.

Rosfjord, E. and A. Rizzino. 1994. The octamer motif present in the Rex-1 promoter binds Oct-1 and Oct-3 expressed by EC cells and ES cells. Biochem. Biophys. Res. Commun. 203: 1795-1802.

Rosner, M.H., M .A. Vigano, K. Ozato, P.M. Timmons, F. Poirier, P.W. Rigby, and L.M. Staudt. 1990. A POU-domain transcription factor in early stem cells and germ cells of the mammalian embryo. Nature 345: 686-692.

Ryan, A.K. and M.G. Rosenfeld. 1997. POU domain family values: Flexibility, partnerships, and developmental codes. Genes \& Dev. 11: 1207-1225.

Saijoh, Y., H. Fujii, C. M eno, M. Sato, Y. Hirota, S. N agamatsu, M. Ikeda, and H. Hamada. 1996. Identification of putative downstream genes of Oct-3, a pluripotent cell-specific transcription factor. Genes Cells 1: 239-252.

Schöler, H.R. 1991. Octamania: The POU factors in murine development. Trends Genet. 7: 323-329.

Schöler, H.R., R. Balling, A.K. Hatzopoulos, N. Suzuki, and P. Gruss. 1989a. Octamer binding proteins confer transcriptional activity in early mouse embryogenesis. EMBO J. 8: 2551-2557.

Schöler, H.R., A.K. Hatzopoulos, R. Balling, N. Suzuki, and P. Gruss. 1989b. A family of octamer-specific proteins present during mouse embryogenesis: Evidence for germline-specific expression of an Oct factor. EMBO J. 8: 2543-2550.

Schöler, H.R., G.R. Dressler, R. Balling, H. Rohdewohld, and P. Gruss. 1990a. Oct-4: A germline-specific transcription factor mapping to the mouse t-complex. EMBO J. 9: 2185-2195.

Schöler, H.R., S. Ruppert, N. Suzuki, K. Chowdhury, and P. Gruss. 1990b. New type of POU domain in germ line-specific protein Oct-4. Nature 344: 435-439.

Schöler, H.R., T. Ciesiolka, and P. Gruss. 1991. A nexus between Oct-4 and E1A: Implications for gene regulation in embryonic stem cells. Cell 66: 291-304.

Schoorlemmer, J. and W. Kruijer. 1991. Octamer-dependant regulation of the KFGF gene in embryonal carcinoma and embryonic stem cells. Mech. Dev. 36: 75-86.
Segil, N., S.B. Roberts, and N. Heintz. 1991. Mitotic phosphorylation of the Oct-1 homeodomain and regulation of Oct-1 DN A binding activity. Science 254: 1814-1816.

Solomon, M.J., P.L. Larsen, and A. Varshavsky. 1988. Mapping protein-DNA interactions in vivo with formaldehyde: Evidence that histone $\mathrm{H} 4$ is retained on a highly transcribed gene. Cell 53: 937-947.

Stephens, L.E., A.E. Sutherland, I.V. Klimanskaya, A. Andrieux, J. Meneses, R.A. Pedersen, and C.H. Damsky. 1995. Deletion of $\beta 1$ integrins in mice results in inner cell mass failure and peri-implantation lethality. Genes \& Dev. 9: 1883-1895.

Stickland, S. and V. Mahdavi. 1978. The induction of differentiation in teratocarcinoma stem cells by retinoic acid. Cell 15: 393-404.

Strickland, S., K.K. Smith, and K.R. Marotti. 1980. Hormonal induction of differentiation in teratocarcinoma stem cells: Generation of parietal endoderm by retinoic acid and dibutyryl CAMP. Cell 21: 347-355.

Sylvester, I. and H.R. Schöler. 1994. Regulation of the Oct-4 gene by nuclear receptors. Nucleic Acids Res. 22: 901-911.

Verrijzer, C.P. and P.C. van der Vliet. 1993. POU domain transcription factors. Biochim. Biophys. Acta 1173: 1-21.

Verrijzer, C.P., J.A. van Oosterhout, W.W. van Weperen, and P.C. van der Vliet. 1991. POU proteins bend DNA via the POU-specific domain. EMBO J. 10: 3007-3014.

Vriend, G. 1990. WHAT IF: A molecular modeling and drug design program. J. Mol. Graph. 8: 52-56.

Vriend, G. and V. Eijsink. 1993. Prediction and analysis of structure, stability and unfolding of thermolysin-like proteases. J. Comput. Aided Mol. Des. 7: 367-396.

Waterhouse, P., R.S. Parhar, X. Guo, P.K. Lala, and D.T. Denhardt. 1992. Regulated temporal and spatial expression of the calcium-binding proteins calcyclin and OPN (osteopontin) in mouse tissues during pregnancy. Mol. Reprod. Dev. 32: 315-323.

Wegner, M., D.W. Drolet, and M.G. Rosenfeld. 1993. POU-domain proteins: Structure and function of developmental regulators. Curr. O pin. Cell Biol. 5: 488-498.

Werner, M.H., J.R. Huth, A.M. Gronenborn, and G.M. Clore. 1995. M olecular basis of human 46X, Y sex reversal revealed from the three-dimensional solution structure of the human SRY-DNA complex. Cell 81: 705-714.

Yeom, Y.I., H.-S. Ha, R. Balling, H.R. Schöler, and K. Artzt. 1991. Structure, expression and chromosomal location of the Oct-4 gene. Mech. Dev. 35: 171-179.

Yeom, Y.I., G. Fuhrmann, C.E. Ovitt, A. Brehm, K. Ohbo, M. Gross, K. Hübner, and H.R. Schöler. 1996. Germline regulatory element of Oct-4 specific for the totipotent cycle of embryonal cells. Development 122: 881-894.

Yuan, H., N. Corbi, C. Basilico, and L. Dailey. 1995. Developmental-specific activity of the FGF-4 enhancer requires the synergistic action of Sox-2 and Oct-3. Genes \& Dev. 9: 26352645.

Zwilling, S., H. Konig, and T. Wirth. 1995. High mobility group protein 2 functionally interacts with the POU domains of octamer transcription factors. EMBO J. 14: 1198-1208. 


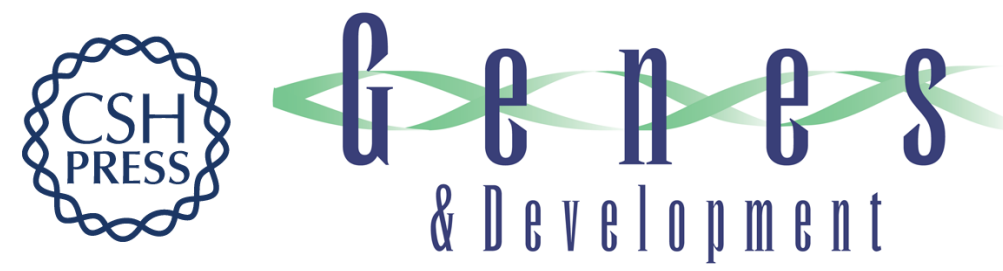

\section{New POU dimer configuration mediates antagonistic control of an osteopontin preimplantation enhancer by Oct-4 and Sox-2}

Valérie Botquin, Heike Hess, Guy Fuhrmann, et al.

Genes Dev. 1998, 12:

Access the most recent version at doi:10.1101/gad.12.13.2073

References This article cites 65 articles, 23 of which can be accessed free at: http://genesdev.cshlp.org/content/12/13/2073.full.html\#ref-list-1

License

Email Alerting

Receive free email alerts when new articles cite this article - sign up in the box at the top Service right corner of the article or click here.

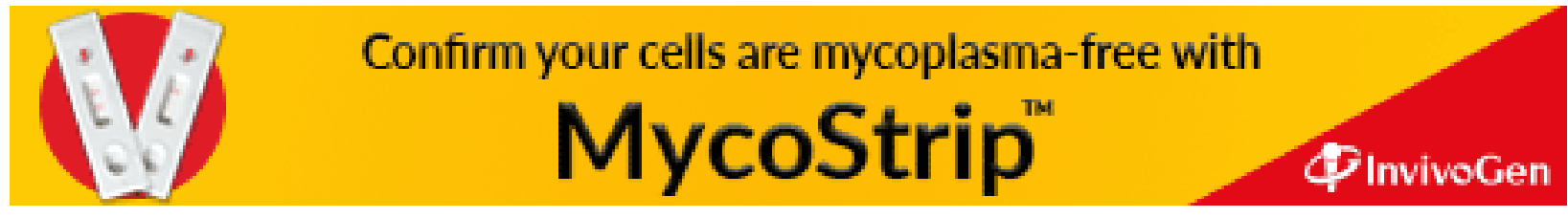

